\title{
Knockout and knockin of the $\beta 1$ exon $D$ define distinct roles for integrin splice variants in heart function and embryonic development
}

\author{
Christian Baudoin, ${ }^{1}$ Marie-José Goumans, ${ }^{2}$ Christine Mummery, ${ }^{2}$ and Amoud Sonnenberg ${ }^{1,3}$ \\ ${ }^{1}$ Division of Cell Biology, The N etherlands Cancer Institute, 1066 CX Amsterdam; ${ }^{2}$ Hubrecht Laboratory, N etherlands \\ Institute For Developmental Biology, 3584 CT Utrecht, The N etherlands
}

The $\beta 1 D$ integrin is a recently characterized isoform of the $\beta 1$ subunit that is specifically expressed in heart and skeletal muscle In this study we have assessed the function of the $\beta 1 D$ integrin splice variant in mice by generating for the first time, Cremediated exon-specific knockout and knockin strains for this splice variant. We show that removal of the exon for $\beta 1 D$ leads to a mildly disturbed heart phenotype, whereas replacement of $\beta 1 A$ by $\beta 1 D$ results in embryonic lethality with a plethora of developmental defects, in part caused by the abnormal migration of neuroepithelial cells. Our data demonstrate that the splice variants $A$ and $D$ are not functionally equivalent. We propose that $\beta 1 D$ is less efficient than $\beta 1 \mathrm{~A}$ in mediating the signaling that regulates cell motility and responses of the cells to mechanical stress.

[Key Words: Integrin; splice variant; muscle; migration; devel opment; knockout; knockin]

Received N ovember 27, 1997; revised version accepted February 6, 1998.

Integrins are widely expressed cell-surface receptors that participate in cell-extracellular matrix (ECM) and cellcell interactions (Hynes 1992; Sonnenberg 1993). Integrins also participate in signal transduction events. In response to ligand binding, they transmit signals that interact with those originating from growth factor receptors to regulate cell growth and differentiation (Schwartz et al. 1995). All integrins are heterodimeric transmembrane proteins, consisting of an $\alpha$ subunit noncoval ently associated to a $\beta$ subunit. At least $16 \alpha$ and $8 \beta$ subunits have been identified. The diversity of the integrin family is further increased by alternative splicing of mRNA. Four isoforms of the $\beta 1$ integrin subunit with different cytoplasmic domains have now been described. The $\beta 1 B$ and the $\beta 1 C$ variants are minor isoforms expressed in some human tissues and cells (Altruda et al. 1990; Languino and Ruoslahti 1992), but they are not found in the mouse (Baudoin et al. 1996). The $\beta 1 D$ variant is the most prominent $\beta 1$ isoform in muscle and is highly conserved between species (van der Flier et al . 1995; Zhidkova et al . 1995; Belkin et al. 1996). $\beta 1 A$ is the most widely expressed $\beta$ integrin subunit and it can associate with at least 10 different $\alpha$ subunits. It is involved in a wide range of biological processes. In development, from fertilization (Almeida et al. 1995) and extending through organogenesis, $\beta 1 \mathrm{~A}$ appears to play a role in the migra-

${ }^{3}$ Corresponding author.

E-MAIL asonn@nki.nl; FAX (31) 205121944. tion of many cell types including the parietal endoderm (Sutherland et al. 1993), myotomal myoblasts (Jaffredo et al. 1988), neuroblasts (Galileo et al. 1992), and neural crest cells (Thiery et al. 1985). In organogenesis, $\beta 1 A$ al so participates in the development of cardiac muscle (Fässler et al. 1996) and facilitates the fusion of myoblasts into myotubes during myogenesis ( $Y$ ang et al. 1996). In addition, $\beta 1$ A plays a role in the migration of various differentiated cell types postnatally, such as keratinocytes and lymphocytes. Finally, recent findings indicate that $\beta 1 \mathrm{~A}$-containing integrins are able to transduce a mechanical force into a biochemical signal, a process known as mechanotransduction (Ingber et al. 1994). Mechanotransduction may be a crucial mechanism for integrating different types of events, such as the forces generated by muscle cells and by cytoskel eton stiffening in migrating cells, during tissue remodeling and neurulation in the developing embryo and the mechanical stresses resulting from local tension, compression, or fluid flow (Gordon and Brodland 1987; Ingber et al . 1994).

The $\beta 1 A$ and $\beta 1 D$ isoforms are very homologous, differing by only 13 amino acids in their cytoplasmic domains, 6 of which are located between the cyto- 2 and cyto-3 domains, resulting in the loss of a potential site for phosphorylation and ILK ( $\beta$ 1-integrin-linked protein kinase) binding in $\beta 1 A$ (Hannigan et al. 1996). In the developing muscle, $\beta 1 D$ is expressed in a specific pattern. It is first detectable late in gestation and later in all types of muscle, that is, fast, mixed, and slow fibers and 
is particularly strongly expressed in the heart, suggesting that it has a crucial function in these tissues (van der Flier et al. 1997). In addition, absence of the integrin $\alpha 7$ subunit, which is the major pairing partner of $\beta 1 D$ in heart and skel etal muscles, causes a novel form of muscular dystrophy (Mayer et al. 1997). Because of its specific localization at myotendinous junctions and at intercalated discs, which represent the major force transmission sites in skeletal and heart muscle respectively, it has been proposed that $\beta 1 D$ mediates stronger attachment at these sites, thereby providing more resistance to the mechanical forces to which muscles are subjected (Belkin et al. 1996; van der Flier et al. 1995). To increase our understanding of the function of $\beta 1 D$, we have knocked out and knocked in the exon for $\beta 1 D$, thereby generating, for the first time, Cre-mediated exon-specific knockout and knockin animals. Adult $\beta 1 D$ knockout mice are viable but displ ay a mild abnormal ity of cardiac function. In contrast, $\beta 1 D$ knockin embryos die during development with multiple defects partly because of abnormal migration of neural cells.

\section{Results}

Generation of $\beta 1$ exon D knockout mice by use of the Cre-loxP system

$\beta 1 D$ is an isoform of $\beta 1$, produced by al ternative splicing of the $\beta 1$ gene. During myogenesis, exon $D$, specific for the $\beta 1 D$ subunit, is spliced into the mature mRNA. To delete exon D in embryonic stem (ES) cells, we have developed a method based on the Cre-loxP system that does not affect the splicing of the remaining exons of the $\beta 1$ gene. In this method, two steps are involved (Fig. 1A): In the first step, exon D together with the ag/gt splicing consensus sites is replaced, through homologous recombination, by a cassette coding for two selection markers flanked by two loxp sites. In the second step, the Cre enzyme is transi ently expressed in the targeted ES cells. Cre catalyzes a loxP site-dependent recombination that efficiently excises the selection marker sequences from the targeted allele, leaving a single loxp site instead of exon D and its splicing consensus sites. The cassette encodes positive and negative selection markers, bacterial neomycin resistance (neor) and herpes simplex thymidine kinase genes (HSV-tk), respectively, linked in tandem and under the control of two separate strong promoters.

The TC 5 targeting construct was designed for homologous recombination (see $M$ aterials and M ethods). E14 ES cells were transfected with the linearized vector and selected for neomycin resistance. Targeted clones were identified by Southern blot analysis, on the basis of a novel 9-kb band in BamHI-digested genomic DNA, detected with probe 331 (Fig. 2A). Homologous recombination was observed in $60 \%$ of cases. The pOG 231 plasmid was used to transiently express the Cre enzyme in two independently targeted ES clones. ES cells that had undergone $C$ re-loxP mediated recombinati on were sel ected with gancycl ovir. The surviving cl ones were screened by

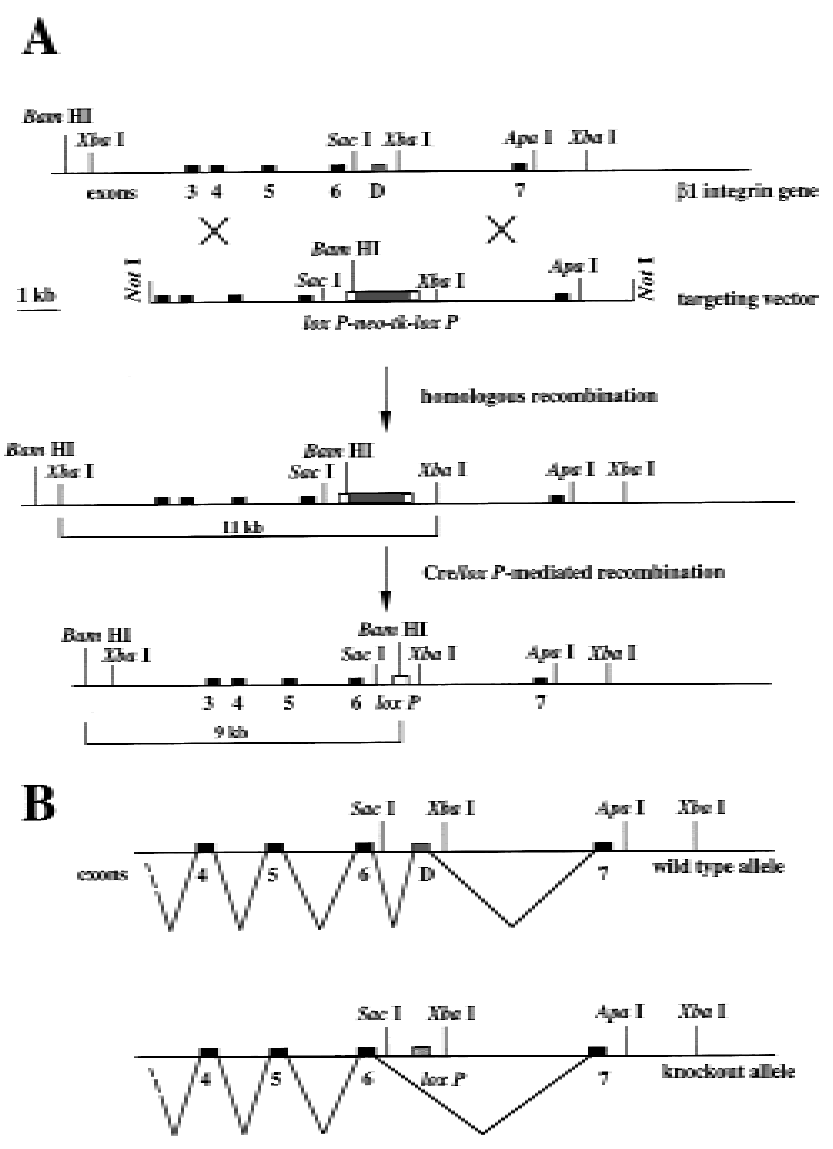

Figure 1. Scheme for exon-specific targeting. (A) Restriction maps for the $3^{\prime}$ portion of the mouse $\beta 1$ integrin locus, the targeting construct, the homol ogous recombinant, and the exon $D$-del eted mutant. In the targeting construct, exon $D$ is replaced by a neo-tk minigene flanked by two loxp sites. After homologous recombination, targeted ES cells are transiently transfected with a Cre-encoding plasmid. After Cre/loxP-mediated recombination, exon $\mathrm{D}$ is replaced by a loxP site. Recombination is detected in Southern blot analysis as a new 9-kb BamHI fragment. The probe (331) is a cDN A consisting of exons 3, 4, 5, and 6. (B) In normal muscle cells, the exon D is inserted into the mature $\beta 1 D$ mRNA, whereas in the knockout muscle cells, exon 6 and 7 are connected leading to the mature $\beta 1 A$ mRNA.

PCR for the deletion event and the replacement of the exon $D$ by a loxP site. We found that in $100 \%$ of the Gancycl ovir-resistant colonies the selection marker was deleted, demonstrating the efficiency of the Cre-loxPmediated recombination. To verify that replacement of exon $D$ by a loxP site did not hamper splicing of the remaining exons (Fig. 1B), PCR and N orthern bl ot analysis were carried out on total RN A extracted from wildtype cells and the mutated ES cell clones. Total RNA was isolated from two independent mutant clones (9D2cre5 and 2G2cre2) and hybridized with a $\beta 1$ cDN A probe (331). The intensity of the signal in the two clones, as estimated by Phosphorlmager analysis, was comparable with that of the parental ES clone (not shown). For PCR analysis, total CDNA from 9D2cre5 and 2G2cre2 


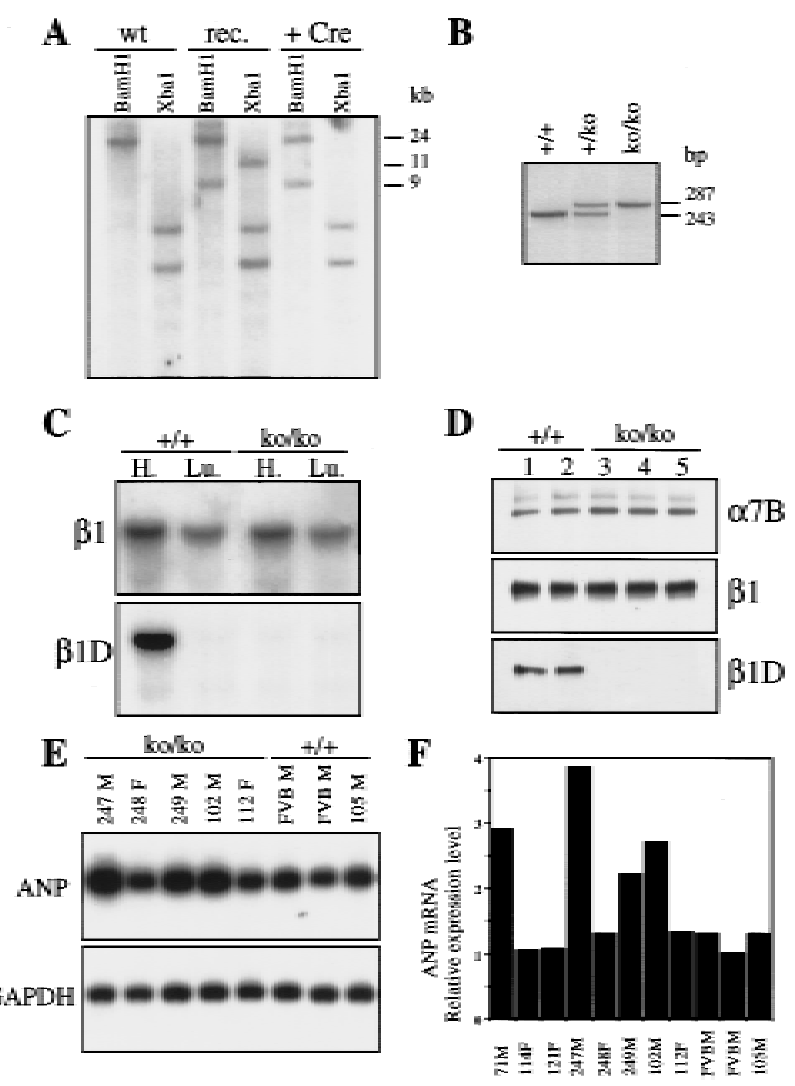

Figure 2. (A) Identification of homologous and Cre/loxP recombination by Southern bl ot analysis of DN A from targeted ES cell lines. A 24-kb fragment is present in BamHI digested DN A from wild-type ES cells (wt), a 9-kb mutated fragment is also present in DNA from homologous-targeted ES cell before (rec) and after (+Cre) the Cre/loxP mediated recombination. In Xbaldigested DNA, an 11-kb fragment is present in the DNA from homologously targeted ES cells, whereas the fragment disappeared after transfection with the Cre-encoding plasmid, showing that the Cre-loxP recombination had been successful. (B) PCR analysis of tail genomic DNA from $t+,+/ k o$, and ko/ko $\beta 1 D$ mice. Primers flank exon $D$; the lower band corresponds to exon $D$ and its consensus splicing sites, the upper band corre sponds to the IoxP site. (C) N orthern blot analysis of mRN A derived from heart and lungs of $+/+$ and $\beta 1 D$ ko/ko mice. The blot is successively probed with an antisense oligonucleotide encoding exon $D(\beta 1 D)$ and exon 7 ( $\beta 1$ ). (D) Immunoblot analysis of proteins extracted from the heart of $+/+$ and ko/ko mice. The blot is successively probed with anti- $\beta 1 D, \beta 1$, and $\alpha 7 \mathrm{~B}$ antibodies. (E) N orthern blot analysis of RNA extracted from ventricles of $+/+$ and $\mathrm{ko} / \mathrm{ko}$ mice. The blot is probed successively with an ANP and GAPDH CDNA probes. (F) Quantification by Phosphorlmager analysis of the rel ative expression level of ANP mRNA in heart ventricles of $t+$ and ko/ko mice. (F) Female; (M) male.

clones were amplified with primers coding for exon 6 and 7. N o PCR products of abnormal size were detected (not shown). These data demonstrate that there was no aberration in the splicing of the $\beta 1$ gene. The 9D 2cre5 and 2G 2cre2 ES cl ones were injected into C57BL/ 6 blastocysts and chimeras were obtained. These chimeras successfully all owed germ-line transmission for the two clones and were crossed with FVB or 129/OLA females. Heterozygous offspring was then interbred to produce homozygous mutants, and offspring was tested for exon D deletion by Southern blot and PCR analysis (Fig. 2B).

The muscles of the $\beta 1 \mathrm{D}$ knockout mice do not have detectable $\beta 1 \mathrm{D}$ mRNA or $\beta 1 \mathrm{D}$ protein

$N$ orthern blot analysis, performed with a $\beta 1$ probe that detects both $\beta 1 \mathrm{~A}$ and $\beta 1 \mathrm{D}$ transcripts revealed a single transcript of $3.5 \mathrm{~kb}$ in the heart and the lungs of the wild-type $(+/+)$ and knockout/knockout (ko/ko) mice (Fig. 2C). Phosphorlmager analysis indicated that thelevels of $\beta 1 \mathrm{mRNA}$ in ko/ko mice were comparable with those in $+/+$ mice. Subsequent hybridization with a $\beta 1 D$ specific oligonucleotide showed that the $3.5-\mathrm{kb} \beta 1 \mathrm{D}$ mRNA was present only in our $H+$ mice (Fig. 2C). To verify that $\beta 1 D$ protein was absent from these animals, we performed immunoblot analysis using the monoclonal antibody, 2B1, which is specific for $\beta 1 \mathrm{D}$ (van der Flier et al. 1997). As shown in Figure 2D, the antibody recognizes a band of $120 \mathrm{kD}$ in the heart of the $+/+$ but not the ko/ko animals. Probing with a total anti- $\beta 1$ antibody reveal ed that the amounts of $\beta 1$ protein were similar in the $H+$ and the ko/ko mice, suggesting that there was an increase in the expression of $\beta 1 \mathrm{~A}$ in the heart of $\mathrm{ko} / \mathrm{ko}$ mice (Fig. 2D), which was confirmed by probing with a $\beta 1 A$ antibody (not shown).

There are no histological or ultrastructural al terations in muscles of $\beta 1 D$ knockout mice

Despite a highly specific expression pattern of $\beta 1 D$ in developing muscle (van der Flier et al. 1997), mice homozygous for the $\beta 1 \mathrm{D}-\mathrm{knockout}$ allele were viable and fertile. They could not be distinguished from control animals by overall morphology and behavior. Mice were able to run, swim, or hold a weighted grid without any obvious signs of fatigue as compared with littermate control mice. Light microscopy studies on sections of muscles from the diaphragm, soleus, vastus lateralis, gastrocnemius, tibial is anterior, and heart muscles from $\beta 1 \mathrm{D} \mathrm{ko} / \mathrm{ko}$ mice up to 1 year of age, did not reveal any obvious morphological abnormalities characteristic for muscular dystrophies. Also, no necrosis or polynuclear infiltration, characteristic of fiber degeneration/regeneration cycles, were detected. In addition, the myocardium did not show any signs of hypo- or hypertrophy, and no calcium or collagen deposits were present as assessed by von Kossa and Masson trichrome staining. Finally, electron microscopical analysis did not reveal any abnormalities at the sites in which $\beta 1 D$ is normal ly enriched; in skeletal muscles, myotendinous junctions were normally folded with digit-like extensions of the muscle cells into the collagen fibrils. In the heart, myofibrils were correctly organized with a normal lateral alignment, particularly at the intercalated discs (not shown).

To assess whether the distribution of some specific proteins might be affected as a consequence of the loss of 
$\beta 1 D$, we performed immunofluorescence microscopy on frozen sections of skeletal and cardiac muscle from $+/+$ and $\beta 1 D$ ko/ko mice. Because in cardiac and skeletal muscles the $\alpha$ 7A and $\alpha 7 \mathrm{~B}$ subunits are the major pai ring partners for $\beta 1 D$ (Belkin et al . 1996), we first checked for staining for these subunits using isoform specific antibodies on frozen sections of $+/+$ and $\beta 1 D$ ko/ko mice. No differences were observed with respect to the distribution or the expression levels of the $\alpha 7 \mathrm{~A}$ and $\alpha 7 \mathrm{~B}$ subunits (Fig. 3G-J). Western blot and Phosphorlmager analysis reveal ed that the quantity of $\alpha 7 \mathrm{~B}$ protein was the same in the hearts of the $H+$ and the ko/ ko mice (Fig. 2D), which suggests that there is no preferential association of the $\alpha 7$ subunit with $\beta 1 A$ or $\beta 1 D$ and that the stability of the $\alpha 7 \beta 1 D$ integrin is not different from that of $\alpha 7 \beta 1 A$. Staining with anti- $\alpha 3$ and anti- $\alpha 5$ antibodies, which are known to be expressed in the connective tissue and blood vessels present in muscle tissue, also revealed no differences (not shown). Laminin 2 (merosin) is the major laminin isoform found in the extracellular matrix of skeletal and heart muscles and it is a ligand for the $\alpha 7 \beta 1$

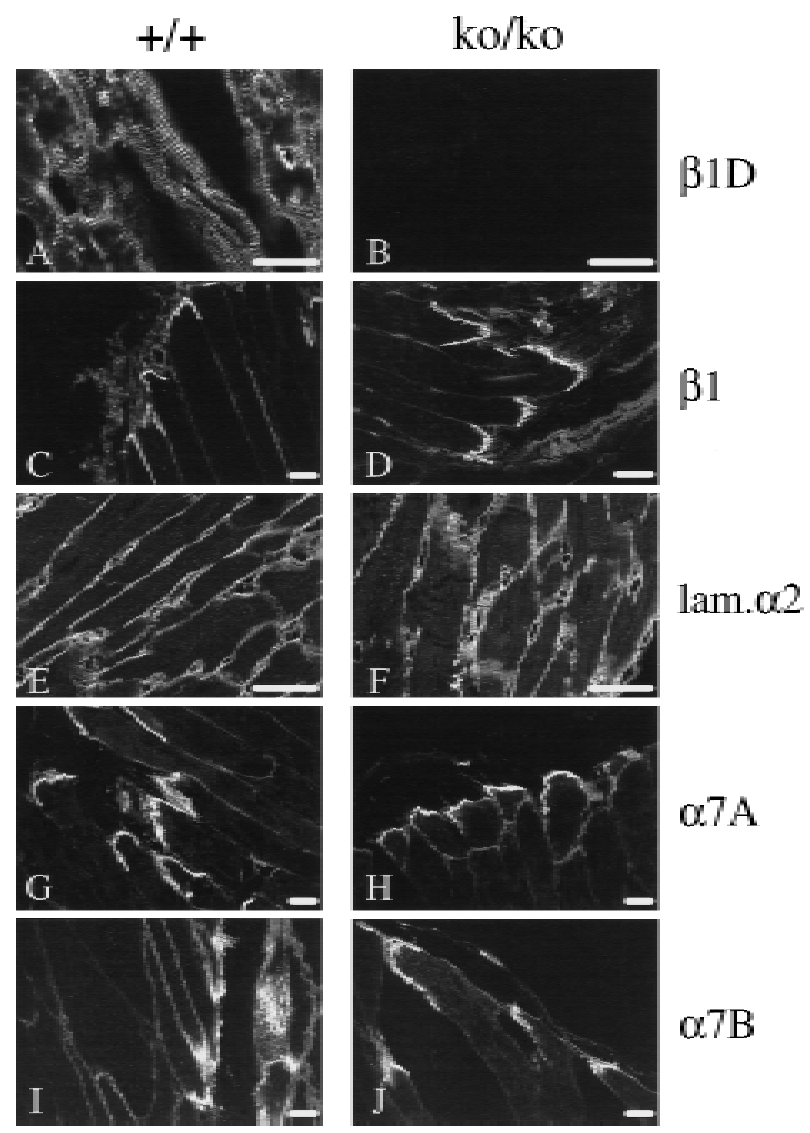

Figure 3. (A-J) Immunostaining of skel etal muscles from $\beta 1 D$ $H+$ and ko/ko mice. Skel etal muscles of 1-year-old mice were frozen in OCT compound, and sections were prepared and subjected to immunofluorescence histochemistry with various antibodies. The first section of each pair is from $H+$ skeletal muscles; the second is from ko/ko skel etal muscles. $(A, B)$ anti$\beta 1 D$; $(C, D)$ anti- $\beta 1$; $(E, F)$ anti- $\alpha 2$ laminin subunit; $(G, H)$ anti$\alpha 7 A$ integrin; $(I, J)$ anti- $\alpha$ 7B integrin. Scale bars, $25 \mu \mathrm{m}$. integrin (Velling et al. 1996; Y ao et al . 1996). Staining of muscles with an anti- $\alpha 2$ laminin subunit antibody again revealed no differences with respect to localization or the level of expression (Fig. 3E,F). Finally, we stained sections with an anti-dystrophin antibody to investigate whether the dystrophin-dystroglycan complex may compensate for the loss of $\beta 1 D$. No change in staining was observed in muscles of $\beta 1 \mathrm{D}$ ko/ko mice. Thus, we conclude that the absence of $\beta 1 D$ does not influence the localization or the level of expression of these proteins and that $\beta 1 D$ deletion does not result in obvious histological or ultrastructural abnormalities.

\section{$\beta 1 D$ knockout mice display mild cardiac functional abnormalities}

Because functional abnormalities may precede morphological changes, we analyzed our mice using markers of functional alteration in muscle. We focused on the function of the myocardium because the expression level of $\beta 1 D$ is 5 - to 10 -fold higher in cardiac than in skeletal muscle (van der Flier et al. 1997). The amount of atrial natriuretic peptide (ANP) is a biological marker for the severity of heart dysfunction and predictive for patients' survival. In ventricles of patients with left ventricular hypertrophy and a failing heart, or in rats with congenital cardiomyopathies, AN P synthesis is increased twoto sixfold as a haemodynamic functional compensatory mechanism (Brooks et al. 1988; Lee et al. 1988; M orita et al. 1990). We hybridized total RN A extracted from the ventricles of the $\mathrm{ko} / \mathrm{ko}$ and $+/+$ mice with an ANP cDNA probe. The level of ANP mRN A was significantly increased (two to six times) in $100 \%(15 / 15)$ of the male ko/ko mice compared with controls, whereas no such increase was observed in the female ko/ko mice (0/8) (Fig. 2E-F). In nine wild-type littermates (six males, three females) no differences in the ANP mRNA levels were detected. In addition, we found that in two male $\beta 1 D$ $\mathrm{ko} / \mathrm{ko}$ mice $(2 / 2)$ the level of the $\beta$ myosin heavy chain $(\beta \mathrm{MHC})$, the amount of which is also a marker of heart dysfunction (Izumo et al. 1987), was elevated by $25 \%$, thus confirming ventricular dysfunction and a compensatory response (Dr. G.S. Buttler-Browne, pers. comm.). As an additional control, the AN P probe was al so hybridized with mRNA extracted from $10 \alpha 6 \mathrm{~A}$ ko/ko mice (five males, five females). Although the $\alpha 6 A$ integrin subunit is expressed in the heart during development, its absence did not result in an increase of the AN P mRNA level (Dr. C. Gimond, pers. comm.). These results show that male $\beta 1 D$ ko/ko mice have a mildly affected heart phenotype, as reflected by an increased expression of ANP and $\beta M H C$ in the ventricles.

Generation of $\beta 1$ exon D knockin mice: the complementary approach to the $\beta 1 \mathrm{D}$ knockout

Gene knockin is an approach in which a gene is replaced by another to test whether the product of the two genes are functionally equivalent. To check whether $\beta 1 D$ can 
take over $\beta 1 A$, we replaced part of the gene specifically encoding $\beta 1 A$ by a cDNA fragment encoding $\beta 1 D$. To produce $\beta 1 D$ knockin/knockin (ki/ki) mice, we designed the TC 8 targeting construct for the sel ective expression of the $\beta 1 D$ subunit (Fig. 4A). ES cells were transfected with the targeting construct and selected for neomycin resistance. Homologous recombination was identified by Southern blot analysis of BamHI-digested genomic DN A on hybridization with the probe 331 . Recombination can occur via the $5^{\prime}$ and $3^{\prime}$ arms of the construct resulting in a novel 9-kb band (type 1 targeting), or can occur via the $5^{\prime}$ arm and the region located between exon 7 of the neo gene resulting in a novel 14-kb band (type 2 targeting) (Fig. 5A). A high frequency (55\%) of homologous recombination was achieved. Two independently targeted

\section{A}
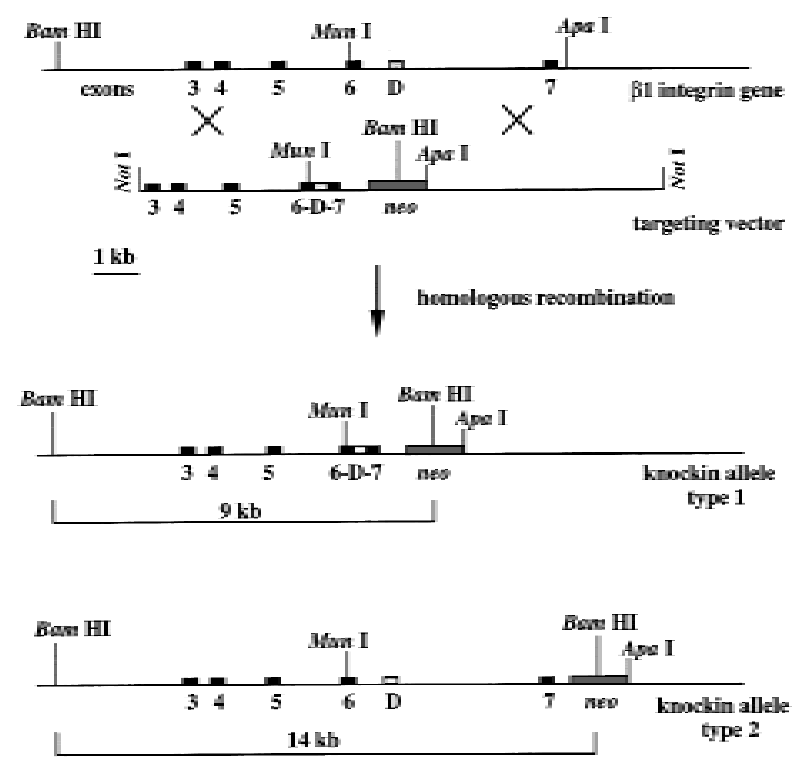

B

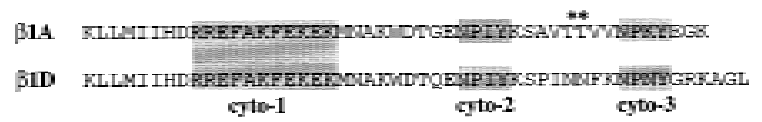

Figure 4. (A) Knockin targeting strategy. Restriction maps for the $3^{\prime}$ portion of the mouse $\beta 1$ integrin locus, the targeting construct, and the type 1 and 2 homologous recombinants. Homologous recombination occurs between the $5^{\prime}$ and the $3^{\prime}$ end of the construct with the genomic DNA leading to the type 1 recombinant DNA or between the $3^{\prime}$ end and the connecting region between exon 7 and the neo gene with the genomic DN $A$ leading to the type 2 recombinant DNA. After digestion with BamHI, the ES cell DNA is probed with 331, giving a wild-type $24-\mathrm{kb}$ fragment and targeted 14- or 9-kb fragments. (B) The amino acid sequences of the $\beta 1 \mathrm{~A}$ and $\beta 1 \mathrm{D}$ cytoplasmic domains differ after the KWDT sequence. The conserved cyto-1, cyto-2, and cyto-3, which are important for the localization of integrins in focal contacts, are shaded. $N$ ote that the two threonines $\left(^{*}\right)$ present in the $\beta 1 \mathrm{~A}$ integrin are absent in the $\beta 1 \mathrm{D}$ integrin.

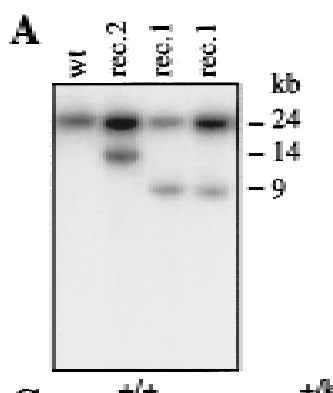

B
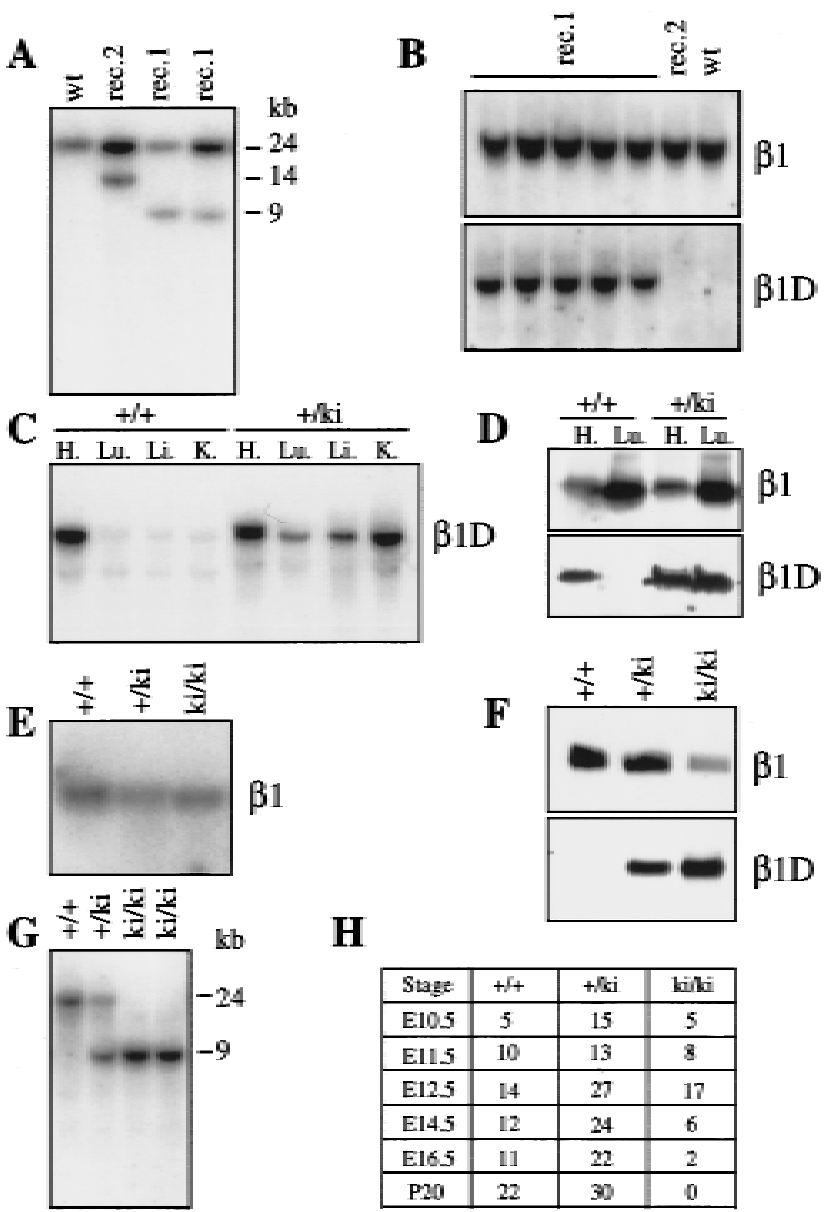

H

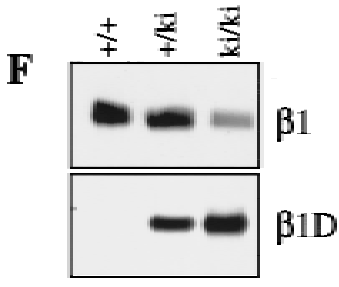

Figure 5. (A) Identification of type 1 and type 2 homologous recombination by Southern blot analysis of DNA from targeted ES cell lines. After digestion with BamHI, DNA is probed with 331. The 24-kb fragment is the wild-type allele (wt), the 9-kb and the $14-\mathrm{kb}$ fragments are the type 1 (rec. 1 ) and type 2 (rec. 2) mutated al lel es, respectively. (B) N orthern bl ot analysis of RN A from total ES cells. The type 1-targeted ES cells (rec. 1) express $\beta 1 D$ after homologous recombination. The blot was successively hybridized with an antisense oligonucleotide encoding for exon $D(\beta 1 D)$ and exon 7 ( $\beta 1)$. (C) $N$ orthern blot analysis of RNA from total tissues of heterozygous knockin mice. After knockin recombination, $\beta 1 \mathrm{D}$ is constitutively expressed in all the tissues analyzed, i.e., heart (H.), lungs (Lu.), liver (Li.), and kidneys (ki.). (D) Western blot analysis of proteins from total tissues of heterozygous knockin mice. Mice expressing $\beta 1 D$ at the mRN A level (see Fig. 6C) express $\beta 1 D$ at the protein level. (E) N orthern blot analysis of total RN As derived from knockin MEFs in culture. The wild-type $t+$, heterozygous $t / k i$, and homozygous ki/ki $\beta 1 \mathrm{D}$ knockin MEFs express $\beta 1 \mathrm{mRNA}$ at the same level. The blot was hybridized with probe 331, which recognizes all $\beta 1$ isoforms. (F) Western blot analysis of proteins from a total lysate of MEFs. ki/ki MEFs express $\beta 1 D$. N ote the higher expression level of $\beta 1$ in the $H+$ MEFs compared with the ki/ki MEFs. (G) Southern blot analysis of DN A derived from knockin embryos. In ki/ki embryos, only the type 1 mutated allele $(9 \mathrm{~kb})$ is present. The blot was hybridized with $331 .(\mathrm{H})$ Genotypes of progeny from intercrosses between heterozygous $\beta 1 D$ knockin parents. 
clones, 7A1 and 2B1, were injected into C57BL/ 6 blastocysts and chimeras were obtained. These chimeras successfully gave germ-line transmission for the mutated allele and produced heterozygous offspring when crossed with FVB and 129/OLA females.

$\beta 1 D$ is ubiquitously expressed in targeted ES cells and in heterozygous $\beta 1 D$ knockin mice

To assess whether the type 1 homologous recombination resulted in the expression of $\beta 1 D$ mRN A, we performed $\mathrm{N}$ orthern blot analysis of total RN A extracted from targeted ES cells and tissues from heterozygous knockin mice. RN A samples were probed with a radiolabeled antisense ol igonucleotide specific for $\beta 1 \mathrm{D}$. The 3.5-kb $\beta 1 \mathrm{D}$ mRN A was detected in the type 1 targeted ES cell clones (Fig. 5B) and in different tissues from heterozygous $\beta 1 D$ knockin mice (Fig. 5C). In contrast, no signal was detected with mRNA from wild-type and type 2 targeted clones (Fig. 5B). To quantify the total amount of $\beta 1$ mRN A, an antisense oligonucl eotide for $\beta 1$ (exon 7) was hybridized with the different blots (Fig. 5B). The level of the $\beta 1 D$ mRNA, in type 1 targeted ES cells and in $\beta 1 D$ $+/ \mathrm{ki}$ mice, was $50 \%$ of that of $\beta 1$ mRNA, because $\beta 1 D$, in type 1 targeted ES cells and $\beta 1 D+/ k i$ mice is expressed by only one allele. Finally, we performed Western blot analysis using the monoclonal antibody 2B1, specific for $\beta 1 D$, to investigate whether the $\beta 1 D$ protein is expressed in $\beta 1 D+/ k i$ mice. As shown in Figure 5D, a
120-kD protein is detected in both heart and lung of heterozygous $\beta 1 D$ knockin mice, demonstrating that the homologous recombination has led to the constitutive expression of $\beta 1 D$.

\section{$\beta 1 D$ homozygous knockin is embryonic lethal}

$\mathrm{N}$ ext, we investigated whether the exclusive expression of $\beta 1 D$ had morphological consequences in heterozygous knockin adult mice. Anatomical and light microscope analysis of tissue sections of $\beta 1 D+/ k i$ mice showed no obvious signs of degeneration suggesting that $\beta 1 D$ does not act as a dominant negative with regard to $\beta 1 \mathrm{~A}$ function.

Strikingly, crossing heterozygous $+/ k i$ mice did not result in any live-born homozygous $\beta 1 \mathrm{D}$ knockin ki/ki pups. Therefore, we determined the developmental age at which the embryos were lost. Twenty percent of the embryos recovered at $10.5 \mathrm{dpc}$ were genotyped as $\mathrm{ki} / \mathrm{ki}$, whereas at $16.5 \mathrm{dpc}$ this was only 6\% (Fig. 5H). Embryos were collected at vari ous ages between 10.5 and $16.5 \mathrm{dpc}$, genotyped, analyzed for gross anatomical changes, and for histological and immunohistochemical analysis sections were prepared. At $10.5 \mathrm{dpc}$, ki/ki embryos were morphologically indistinguishable from $H+$ and $+/ k i$ embryos (data not shown). At $11.5 \mathrm{dpc}$, however, about one-third of the ki / ki embryos were obviously abnormal, as shown in Figure $6(B-I)$, compared with $H+$ or $+/ k i$ (Fig. 6A) at the same age. The neural tube was open, and
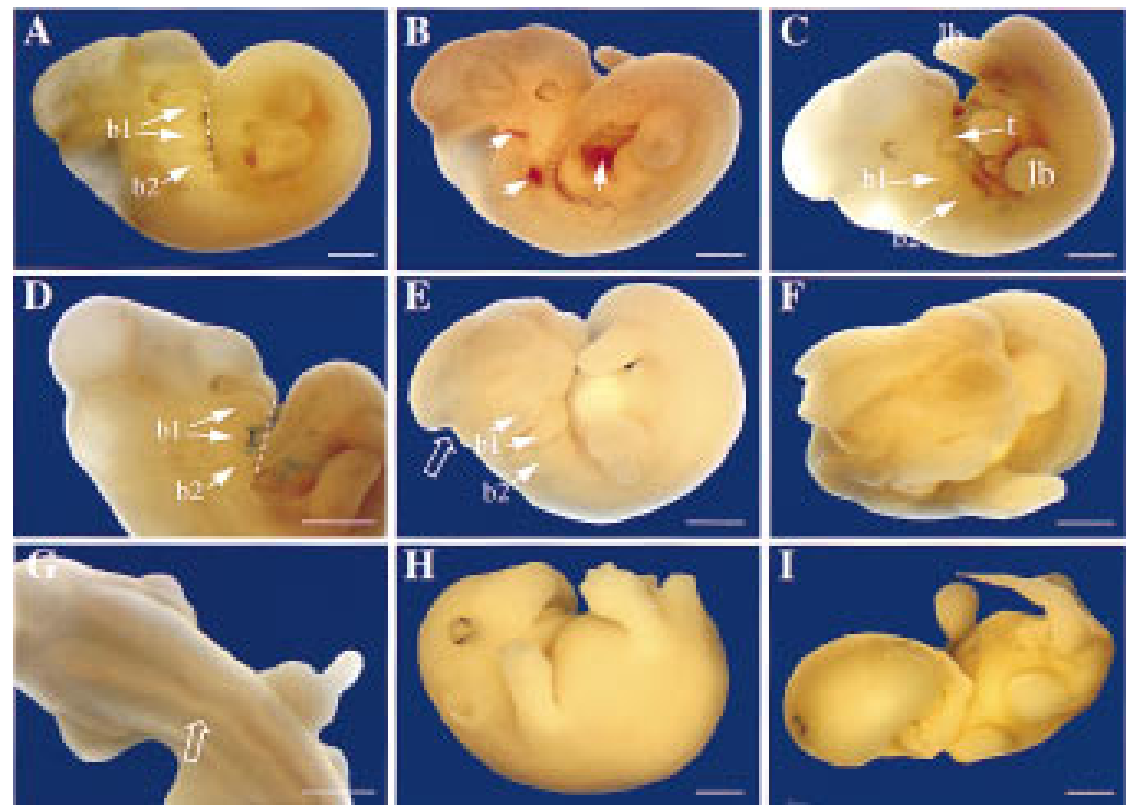

Figure 6. Phenotype of $\beta 1 \mathrm{D} \mathrm{ki/ki} \mathrm{em-}$ bryos between 11.5 and $16.5 \mathrm{dpc}$. Gross morphology is shown at $11.5(\mathrm{~A}-\mathrm{G})$ and $16.5 \mathrm{dpc}(\mathrm{H}, \mathrm{I})$. (A) Control $+/ \mathrm{ki}$ embryo at $11.5 \mathrm{dpc}$. The neural tube is closed rostrally and caudally; brain cavities are evident as convolutions in the head; the tail bends to the right, with developing limbs symmetrically positioned on either side. The broken line joins ventral extremities of first and second branchial arches (b1, b2). In b1, the maxillary (top) and mandibular (bottom) components are al ready separating. (B) $\beta 1 \mathrm{D} \mathrm{ki/ki} \mathrm{embryo} \mathrm{at} 11.5$ dpc showing extravasation of RBCs (arrows). (C) $\beta 1 \mathrm{D} \mathrm{ki} / \mathrm{ki}$ embryo at $11.5 \mathrm{dpc}$ showing that the maxillary component of the first branchial arch (b1) is missing, leaving the tongue (t) exposed. The limbs (lb) are excentrically positioned with re spect to the tail. (D) $\beta 1 \mathrm{D} \mathrm{ki} / \mathrm{ki}$ embryo at $11.5 \mathrm{dpc}$ showing abnormal development of the first branchial arch (b1) with the mandibular component missing. The bro-

ken line joins ventral extremities of b1 and b2. (E) $\beta 1 \mathrm{D} \mathrm{ki/ki} \mathrm{embryo} \mathrm{at} 11.5 \mathrm{dpc}$ showing lack of part of the hindbrain (open arrow). The body is also abnormally twisted with lower limbs excentrically placed relative to the tail and branchial arches b1 and b2 are underdevel oped. (F) A nterior view of embryo in E showing open neural tube. (G) Dorsal view of a $\beta 1 D \mathrm{ki} / \mathrm{ki}$ embryo at $11.5 \mathrm{dpc}$ showing a kinked neural tube (open arrow). (H) $\beta 1 \mathrm{D} \mathrm{ki} / \mathrm{ki}$ embryo at $16.5 \mathrm{dpc}$. The shortened branchial arch has resulted in an underdeveloped lower jaw, so that the upper pal ate is visi ble. The head is abnormal ly smooth. (F) $\beta 1 \mathrm{D} \mathrm{ki} / \mathrm{ki}$ embryo at $16.5 \mathrm{dpc}$. Both jaws and the lower part of the face are underdevel oped and misformed. One eye has been displaced to the top of the head, probably by edema (arrow). All limbs have retarded digit devel opment. Scale bars, $1.2 \mathrm{~mm}$. 
abnormally waved both rostrally and caudally (Fig. $6 F, G$ ), some embryos lacked part of the hindbrain (Fig. $6 \mathrm{E})$ and in most embryos, the first branchial arch was shortened (Fig. 6, cf. D and E with control A). In several embryos, this left the tongue exposed (Fig. 6C), where it would normally have been enclosed by developing jaws. At $12.5 \mathrm{dpc}$, this pattern of abnormalities was maintained (data not shown). Conventional histology on transverse sections at $12.5 \mathrm{dpc}$ showed that the open anterior neural tube in $\mathrm{ki} / \mathrm{ki}$ embryos was accompanied by a gross expansion of the neuroepithelium (Fig. 7B), in a pattern different from that observed in $+/ k i$ embryos in which the neural tube was closed at that level (Fig. 7A). Because the overall phenotype bears resemblance to that described for fibronectin (FN) ko/ko embryos and because the migratory behavior of embryonic fibroblasts isolated from ki/ki embryos at this stage on FN substrates was altered (see below), we stained adjacent sections for FN (Fig. 7C,D) and its major receptor subunit, the $\alpha 5$ integrin subunit (Fig. $6 \mathrm{I}, \mathrm{J})$. In the $H+$ (not shown) and $+/$ ki embryos (Fig. 7C), FN antibodies stained a thin (cellular) layer surrounding the neural tube, the endothelial cells of blood vessels, a layer around the somites and weakly, mesenchymal cells under the neural tube. The neuroepi thel ium and somites themselves were negative. In contrast, the $\beta 1 \mathrm{D} \mathrm{ki/ki} \mathrm{embryos} \mathrm{lacked} \mathrm{the} \mathrm{thin} \mathrm{layer}$ of staining around the open neural tube (Fig. 7D), whereas more caudal ly in the same embryo, in which the tube was closed, staining appeared to be normal (data not shown). In the mesenchyme under the open neural tube, staining of FN was abnormally strong, whereas staining of FN was normal in the walls of the aorta, but in smaller vessels, levels appeared to be reduced (not shown). This may have resulted in weaker vessel walls and extravasation of red blood cells (RBCs) was evident in various tissues of the ki/ki embryos (Fig. 7H), whereas in contrast, in $+/ k i$ embryos, RBC s were only contained within vessels (Fig. 6K). RBCs were al so found in the pericardial cavity of the ki/ki embryos (Fig. $7 \mathrm{H}$ ), but not in the $+/ \mathrm{ki}$ embryos (Fig. 7G) or $H+$ embryos (data not shown). Where extravasation had occurred just under the skin, patches of RBC s were evident immediately on dissection of the ki/ki embryos from the uterus (Fig. 6B), whereas they were not seen in the $H / k i$ (Fig. 7A) or control $H+$ embryos (data not shown). The expression and distribution of the FN receptor, $\alpha 5 \beta 1$, was unal tered in the $\mathrm{ki} / \mathrm{ki}$ embryos. The thin layer of $\alpha 5$ around the neural tube seemed to be completely intact (Fig. $7 \mathrm{l}, \mathrm{J}$ ). Other tissues of the ki/ ki embryos at $12.5 \mathrm{dpc}$ and compared with $+/ \mathrm{ki}$ and $+/+$ tested in serial transverse and sagittal sections included the trigenimal ganglion (V), choroid pl exus, optic nerve (II), diencephal on, fore and hindbrain, Jacob-
Figure 7. Histological sections of control and $\beta 1 \mathrm{D} \mathrm{ki} / \mathrm{ki}$ embryos stained with hematoxilin and eosin. (A) Transverse section of control $+/$ ki embryo (12.5 dpc) at the level of the hind limbs. The embryo is curved so that the anterior (a) and posterior ( $p$ ) neural tubes $(n)$ are visible and closed. (B) Transverse section of $\beta 1 \mathrm{D} \mathrm{ki} / \mathrm{ki}$ embryo (12.5 dpc) at the level of the hind limbs. The neural tube $(n)$ is open and the neuroepithelium overexpanded. Twisting of the body results in an abnormal a-p axis. (C) FN staining of a control $+/$ ki embryo (12.5 dpc) (transverse section through the anterior neural tube). N ote the thin layer around the neural tube, the low level of staining in the mesenchyme ventral to the neural tube (solid arrow) and the strong staining around the aorta (ao). (D) FN staining of a $\beta 1 \mathrm{D} \mathrm{ki} / \mathrm{ki}$ embryo (12.5 dpc) (transverse section through the anterior neural tube that had failed to close). Note the lack of a thin layer of FN around the neural tube (open arrow), excessive $\mathrm{FN}$ in the mesenchyme underlying the neuroepithelium (solid arrow), but the normal amounts of FN around the aorta (a). (E) Sagittal section through the head of a control $+/ \mathrm{ki}$ embryo at $14.5 \mathrm{dpc}$ showing the choroid plexus (cp) in the roof of the fourth ventricle. (F) Sagittal section through the head of a $\beta 1 \mathrm{D} \mathrm{ki} / \mathrm{ki}$ embryo at $14.5 \mathrm{dpc}$ at the position that should contain the choroid plexus (arrow). The head of this embryo is smooth, as in Fig. $6 \mathrm{H}$. (G) Sagittal section through a control $+/$ ki embryo showing RBC s confined within blood vessels [(da) dorsal aorta]. (H) Sagittal section through a $\beta 1 \mathrm{D} \mathrm{ki} / \mathrm{ki}$ embryo showing RBCs dispersed throughout the tissue and in the pericardial cavity (pc). (I) $\alpha 5$ integrin staining of a control $+/ \mathrm{ki}$ embryo at $12.5 \mathrm{dpc}$. Transverse section adjacent in the anterior neural tube. $\mathrm{N}$ ote staining of the same thin layer around the neural tube as in C. (J) $\alpha 5$ integrin staining of a $\beta 1 \mathrm{D} \mathrm{ki} / \mathrm{ki}$ embryo at $12.5 \mathrm{dpc}$. Transverse section through the anterior neural tube that had failed to close. The thin layer around the neural tube is stained as in controls in which the tube is closed at the same level. Scale bars, $1 \mathrm{~mm}$ in A-D, $150 \mu \mathrm{m} \mathrm{E-J.}$ 
son's organ, tongue, jaws, ventricles and atria, pericardial cavity, septum and outflow tract, body wall, liver, gut, notochord, urogenital tract, spinal cord, dorsal root ganglia, mesonephros, metanephros, gonads, lung, vagus nerve (X), cartilage, somites, stomach, eye, facial ganglion (VII), and main veins and arteries. Of these, only the choroid plexus was markedly aberrant. Only a rudimentary choroid plexus was present in some sections of a complete series, cut saggitally through the head from the roof of the fourth ventricle (Fig. 7E,F). Its virtual absence correlates with the presence of an abnormally smooth head and small brain cavities, features that were also evident at later stages of development (16.5 dpc) in $\mathrm{ki} / \mathrm{ki}$ embryos (Fig. 6H). At these late stages, only two embryos were recovered, both of which were abnormal (Fig. 6H, I). A striking feature was the lack of a lower jaw and a dysmorphic lower face, most likely caused by an underdevel opment of the first branchial arch. The heart of the embryos shown in Figure $6 \mathrm{H}$ was no longer beating when collected at $16.5 \mathrm{dpc}$, but development of the ear shows that it was viable until at least $15.5 \mathrm{dpc}$. Finally, in one embryo, digit formation was delayed in all limbs (Fig. 6l), compared with $H+$ littermates (Fig. $6 \mathrm{H}$; data not shown). These results clearly demonstrate that $\beta 1 D$ cannot replace the function of $\beta 1 A$ during development.

Reduced migratory potential of $\beta 1 D$ knockin embryonic cells

To assess whether the developmental defects that we observed in the ki/ki embryos might be the result of an altered migratory behavior of the ki/ki embryonic cells, we conducted migration and adhesion assays with cultured $12.5 \mathrm{dpc}$ murine embryonic fibroblasts (MEFs) on different extracellular matrix proteins. The genotype of each $12.5 \mathrm{dpc}$ embryo was tested by PCR and Southern bl ot analysis (Fig. 5G) and cells were subcultured three times to obtain a homogenous population of fibroblastic cells. First, we assessed the levels of expression at the cell surface of the $\beta 1, \alpha 1, \alpha 3, \alpha 5$, and $\alpha 6$ integrin subunits and of the $\alpha \mathrm{v} \beta 3$ and $\alpha \mathrm{V} \beta 6$ integrins by immunoprecipitation (Fig. 8B) and FACS analysis (not shown). All of these subunits and integrins were expressed at the cell surface. Interestingly, we found that the expression level of $\beta 1$ was reduced by $50 \%$ in the $\mathrm{ki} / \mathrm{ki} \mathrm{MEFs}$ compared to that in the $H+$ MEFs (Figs. 8B and 5F) and that, consequently, the expression levels of the $\alpha 5, \alpha 3$, and $\alpha 6$ proteins at the cell surface were also reduced by $50 \%$. However, we did not find any difference in the $\beta 1 \mathrm{mRN} A$ level in the ki/ki MEFs compared with that in the $+/+$ MEFs (Fig. 5E). N o difference was found for the $\alpha \vee \beta 3$ and $\alpha \mathrm{V} \beta 6$ integrins.

On laminin 1, we found that both adhesion and migration of the ki/ki MEFs were greatly reduced (Fig. 8A). In the presence of an anti- $\alpha 6$ antibody (GoH3), migration was completely blocked on Iaminin 1 (not shown), indicating that in MEFs $\alpha 6 \beta 1$ is the only laminin- 1 binding integrin. On type IV collagen, we found that migration was reduced, but that adhesion was not al tered. An anti$\beta 1$ antibody completely blocked migration on collagen IV (Fig. 8A), whereas an anti- $\alpha 2$ antibody had no effect (not shown), which is consistent with $\alpha 1 \beta 1$ being the receptor for collagen IV. The level of the $\alpha 1$ integrin sub-
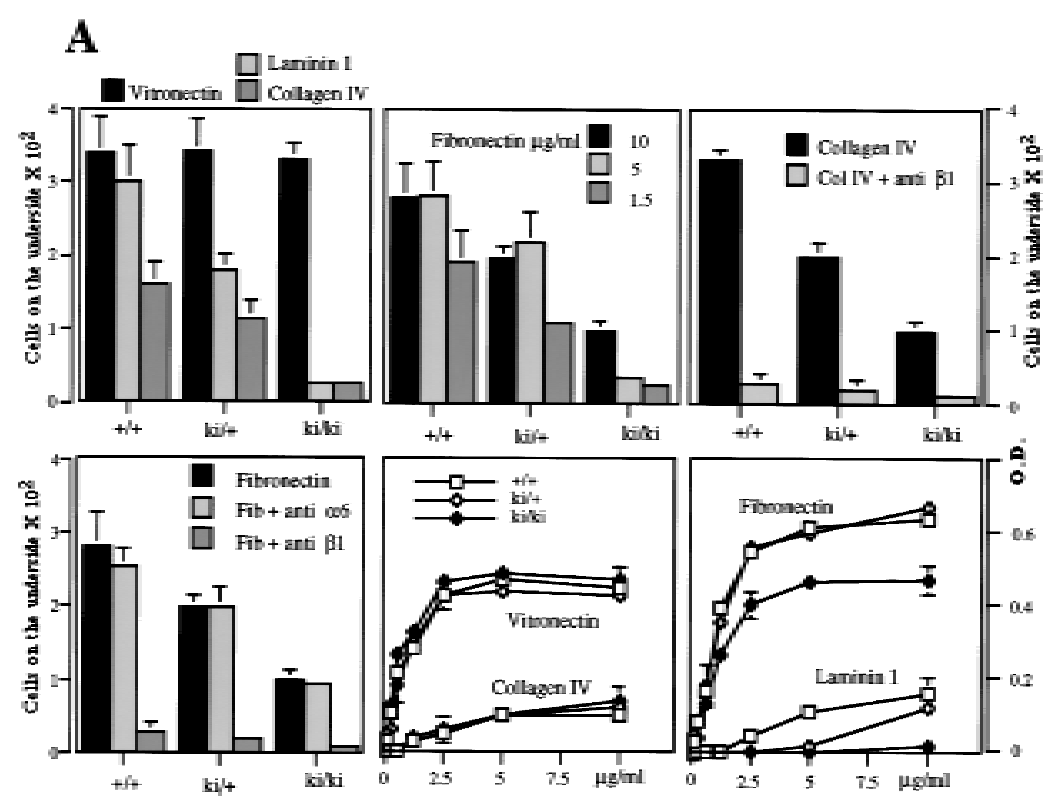

B

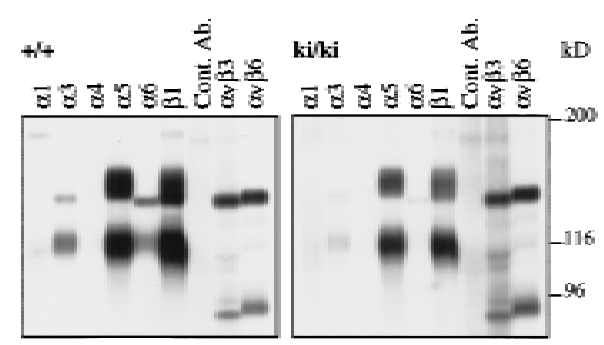

Figure 8. (A) Migratory (bars) and adhesive (lines) properties of $+/+,+/ k i$, and ki/ki MEFs on collagen IV, laminin 1 , vitronectin, and FN. By use of concentrations of FN that result in the same adhesion of $+/+(1.5 \mu \mathrm{g} / \mathrm{ml})$ and $\mathrm{ki} / \mathrm{ki}(5 \mu \mathrm{g} / \mathrm{ml}) \mathrm{MEFs}$ (bottom right), migration is not restored to normal in the ki/ki MEFs. (Top right) Migration on collagen IV is completely blocked with an anti- $\beta 1$ antibody. (Bottom left) Migration on FN is blocked completely by an anti- $\beta 1$ antibody, whereas an anti- $\alpha 6$ antibody has no effect. (B) Immunoprecipitation analysis of various integrin subunits expressed at the surface of the $H+$ and $\mathrm{ki} / \mathrm{ki} \mathrm{MEFs}$. (Cont. Ab.) The secondary antibody used as a control. 
unit was very low but similar on $+/+$ and $\mathrm{ki} / \mathrm{ki}$ MEFs, which is in agreement with the fact that both types of MEFs adhered to a similar extent. Adhesion and migration, on FN, were also reduced in ki/ki MEFs (Fig. 8A). To exclude that the reduced adhesion of the ki/ki MEFs, the result of decreased level of $\beta 1$-containing FN receptors, was responsible for their decreased migration, we performed migration assays using different concentrations of FN. With a concentration of $5 \mu \mathrm{g} / \mathrm{ml}$, adhesion of $\mathrm{ki} / \mathrm{ki}$ MEFs was comparable with that of $+/+$ MEFs at $1.5 \mu \mathrm{g} / \mathrm{ml}$. In spite of that, migration of the ki/ki MEFs was still strongly reduced. An anti- $\beta 1$ antibody completely blocked migration on $F N$, indicating that on MEFs $\beta 1$ containing integrins are the major receptors for FN (Fig. 8A). Finally, we found that when plated on FN, $\mathrm{ki} / \mathrm{ki}$ MEFs formed focal contacts that were similar in size and number to those formed by the $H+$ MEFs (not shown). These results demonstrate that the ki/ki embryonic cells have a reduced migratory potential, which is probably caused by a reduction in the expression of the $\beta 1$ containing integrins, in combination with a lower efficiency of $\beta 1 D$, as compared with $\beta 1 A$, in mediating migration.

\section{Discussion}

Exon-specific knockout and knockin as complementary tools to assess the function of a splice variant protein

Here, we describe the first exon-specific knockout mice to assess the function of a muscle-specific splice variant of $\beta 1$, the $\beta 1 D$ integrin subunit. Because of the numerous biological functions of $\beta 1$, the conventional knockout of the $\beta 1$ gene is embryonically lethal al ready during gastrulation (Fässler et al. 1995; Stephens et al . 1995), so that the function of the $\beta 1 D$ integrin cannot be assessed in these mice. To overcome this problem we have applied a genetic approach on the basis of the Cre-loxP system (Gu et al. 1994; DiSanto et al. 1995; Smith et al. 1995) by which exon D can be specifically deleted. This procedure did not interfere with the germ-line transmission of the mutated gene because chimeric and heterozygous mice were readily obtained. Importantly, the replacement of exon D by a loxP site did not interfere with either the transcription of the $\beta 1$ gene or the stability or the splicing of the $\beta 1$ premRNA, as shown by the normal expression of the $\beta 1$ mRNA in knockout mice (Fig. $2 \mathrm{C}$ ). Finally, translation of the mature RN A al so appears to be normal because the total amount of the $\beta 1$ proteins in muscles from knockout and control mice were similar (Fig. 2D).

In addition, we have al so generated mice that express $\beta 1 D$, instead of $\beta 1 A$, by applying a knockin strategy. This method has been used previously to replace the mouse Engrailed gene En-1 by En-2 (Hanks et al. 1995). Here, we describe, for the first time, the knockin of an exon, replacing the normal mRNA by one encoding one of its splice variants. ES cells were transfected with a construct allowing the constitutive expression of $\beta 1 D$
mRNA. Northern blot analysis of RNA demonstrated that the procedure did not affect the transcription of the $\beta 1$ gene or the stability of the $\beta 1 D$ mRNA, that is, the level of $\beta 1 \mathrm{D}$ in the $\mathrm{ki} / \mathrm{ki}$ MEFs was the same as that of $\beta 1 \mathrm{~A}$ in the $+1+\mathrm{MEFs}$ (Fig. 5E). Furthermore, the knockin procedure did not interfere with the germ-line transmission of the ki gene because the ratio of heterozygous mice was as expected.

In principle, these two complementary techniques, exon-specific knockout and knockin, should allow the activation and inactivation of any exon in any gene. Thus, it is now possible to study the role of splice variants in a genetically modified animal.

What does the knockout tell us about the function of $\beta 1 \mathrm{D}$ in muscles?

Consi dering results of previous studies that indi cate that $\beta 1$ plays an important role in muscle cell differentiation (Fässler et al. 1996), the organization of sarcomeric cytoarchitecture (Volk et al. 1990) and myogenesis (Y ang et al. 1996), we were surprised that in our study the lack of $\beta 1 D$ did not affect muscle formation and did not cause muscular degeneration or myopathy. A likely explanation for this unexpected finding is that loss of the function of $\beta 1 D$ is compensated by $\beta 1 A$. The $\beta 1 D$ isoform is very homologous to $\beta 1 A$; the two variants differ only by 13 amino acids of their cytoplasmic tails (van der Flier et al. 1995; Zhidkova et al. 1995; Belkin et al. 1996). Thus, the phenotype observed in the ko/ko mice is only the result of a different function of the $\beta 1 D$-specific amino acids (Fig. 4B), rather than of the total $\beta 1$ subunit.

In skeletal muscle, $\beta 1 D$ is present at the myotendinous junction and at the costameres. These structures are the major junctions through which the skeletal muscle fiber is connected with the extracellular matrix and the tendon. In the heart, $\beta 1 D$ is found at the intercalated discs that are the structure units for cell-cell contact of the cardiomyocyte (Belkin et al . 1996). In skeletal muscles, $\beta 1 D$ is associated with the $\alpha 7 \mathrm{~A}$ and $\alpha 7 \mathrm{~B}$ subunits, whereas in heart it is only associated with $\alpha$ 7B. Recent work has shown that the cytoplasmic domain of the $\beta P S$ subunit, which is the $\beta 1$ integrin-like subunit in Drosophila, is responsible and sufficient for targeting integrins to the termini of muscles in vivo (Martin-Bermudo and Brown 1996). From these observations, it seems that the cytoplasmic domain of $\beta 1 D$ plays a role in the localization of integrins at these sites. However, in the $\beta 1 \mathrm{D} \mathrm{ko} / \mathrm{ko}$ mice $\beta 1 \mathrm{~A}$ is localized at the same position as $\beta 1 D$ in normal muscle, that is, intercal ated discs, myotendinous junctions, and costameres, which excludes a specific role for $\beta 1 D$ in targeting integrins to these sites. Furthermore, the data suggest that the association of $\beta 1 \mathrm{~A}$ with sarcomeric protein and the actin network is normal and that the role of $\beta 1 D$ is not different from that of $\beta 1 A$ in the maintenance and the organization of the cytoarchitecture of the mature muscle cells. Finally, $\beta 1 D$ ko/ko mice form normal mature muscles, excluding a specific role for $\beta 1 D$ in myogenesis. Because $\beta 1 D$ is highly enriched at the myotendinous 
junctions and in intercalated discs, it has been proposed that $\beta 1 D$ provides stronger attachment at these sites than $\beta 1 A$ (van der Flier et al. 1995; Belkin et al. 1996). Our data do not support this assumption because there are no histological or ultrastructural abnormalities in skeletal and cardiac muscles from ko/ko mice. We also did not observe an increased expression of the dystrophin/dystroglycan complex, which would be a possible compensatory response to a weakening of the attachment of the muscle to the extracellular matrix. Finally, the localization of the $\alpha 2$ laminin subunit appeared to be normal.

What could be the function of the $\beta 1 D$ integrin? The production of isoforms by developmentally regulated alternative splicing of pre-mRNAs is a widespread phenomenon that represents an evolutionary strategy ai med at a subtle functional diversification. Consequently, defining the function of a splice variant protein might be more difficult than of a protein in a total gene knockout. Hence, to identify subtle defects, we anal yzed our ko/ko mice further for functional alterations of the myocardium, because $\beta 1 D$ is 5-10 times more strongly expressed in the heart than in skeletal muscles (van der Flier et al. 1995). In addition, the myocardium is subject to continuous mechanical stress. The amount of ANP is a reliable biological marker for the severity of functional and haemodynamic heart failure. AN P is a 28-amino-acid polypeptide hormone secreted by the heart in response to mechanical and neuroendocrine stimuli (Jarygin et al. 1994; N akao et al. 1996). In early heart failure, ANP synthesis is increased in the ventricles in which it may play a key role in preserving a compensated state of asymptomatic heart dysfunction (Brandt et al. 1993). In humans and hamsters with congestive heart failure and in rats with aortic valve insufficiency, AN P mRN A levels are increased three- to fivefold, respectively, in the ventricles (Brooks et al. 1988; Morita et al. 1990). In addition, ANP mRNA is also increased sixfold in ventricles of rats with spontaneous biventricular hypertrophy (Lee et al. 1988). The finding that in our ko/ko mal e mice the AN P mRN A and the $\beta$ M HC protein levels are increased up to sixfold and by $25 \%$, respectively, is consi stent with a ventricular dysfunction despite the lack of any histological abnormalities or hypertrophic responses.

Why does the absence of $\beta 1 D$ lead to an increased synthesis of AN P? In the heart, AN P is secreted in response to stretch induced by blood pressure that is detected by mainly two factors, that is, pressure-sensitive channel proteins (Erdos et al. 1991), and most likely integrins, which may function as mechanotransducers ( $\mathrm{N}$ ak ao et al. 1996; Shyy and Chien 1997). In light of our results, we speculate that $\beta 1 D$ acts as a mechanotransducer with a reduced sensitivity to the shear force as compared with $\beta 1 \mathrm{~A}$. We suggest that on stretching of muscle cells, the signals elicited by $\beta 1 D$ and $\beta 1 A$ are different. Support for this assumption is derived from the observation that in cultured cells $\beta 1 A$ and $\beta 1 D$ transmit different signals after crosslinking with antibodies (Belkin et al. 1996). Thus, it is conceivable that in our $\beta 1 \mathrm{D} \mathrm{ko/ko} \mathrm{mice,} \mathrm{the}$ $\beta 1 \mathrm{~A}$-mediated reactivity to blood pressure is perturbed, inducing increased synthesis of ANP. This increase in AN P synthesis seems to be sex linked because it was observed in $100 \%$ of the male and $0 \%$ of the female mice. The reason for this is unknown, but we suspect that male mice have a slightly higher blood pressure than female mice. In addition, studies have reported that female rats are more protected against muscle damage following exercise than male rats. This protective effect is probably the result of female sex hormones, particularly estrogens (Tiidus et al. 1995).

What does the knockin tell us about the functions of $\beta 1 \mathrm{~A}$ in development?

The most striking of the defects that we observed was the shortening of the first branchial arches that resulted in an underdeveloped lower mandible (mi crognathia) and an open neural tube. Defective closures, both in the brain (anencephaly) and in the lower spine (myel omeningcele), were evident and, in some cases, were accompanied by an unusual kinking of the back and tail, reminiscent of that described in FN ko/ ko and $\alpha 5 \mathrm{ko} / \mathrm{ko}$ embryos at $8.5 \mathrm{dpc}$ (George et al. 1993; Y ang et al . 1993). FN, which normally surrounds the neural tube, was absent in the region of spina bifida, which suggests that its absence is related to this defect. Poor elongation of the embryonic axis in the $\beta 1 \mathrm{D} \mathrm{ki} / \mathrm{ki}$ embryos accompanied by normal neural tube elongation, however, is a more likely cause of its kinking, as has also been suggested in FN ko/ko embryos. Unexpectedly, the $\alpha 5$ integrin subunit, which we had assumed would bind FN to cells surrounding the neural tube, was normally distributed in the mutant embryos. It is conceivable that $\alpha 5 \beta 1 D$ transmits different signals or interacts with other cystokel etal proteins than $\alpha 5 \beta 1 \mathrm{~A}$ and, thus, affects the assembly of FN in $\mathrm{ki} / \mathrm{ki}$ embryos. This hypothesis is supported by the work of Wu et al. (1995) who have shown that integrin postoccupancy events, requiring the cytoplasmic domain of the $\beta$ chain and an intact cytoskeleton are needed for FN fibrillogenesis. Although other FN -binding integrins may partial ly compensate for $\alpha 5 \beta 1$-induced matrix assembly during development $(Y$ ang and Hynes 1996), their ability to do so is less efficient as compared with that of $\alpha 5 \beta 1$, as was demonstrated with ES cells (Wennerberg et al . 1996), which explains the altered distribution of FN in our ki/ki embryos. Other striking defects that we observed were an abnormally smooth head with poorly expanded brain cavities, in some cases accompanied by a virtual lack of choroid plexus in the roof of the fourth ventricle. We suspect that an altered migratory potential of neuroepithelial cells may underly these alterations. It is al so tempting to speculate that the migratory capacity of the neural crest cells, the major migratory cell population at these mid-gestational stages, is also reduced, because they are an important component of the first branchial arch, in which we observe a defect, and because these cells are thought to be guided to their destination by various extracellular matrix (ECM) molecules, including FN (Morrison-Graham et al. 1992). This hypothesis is supported by the reduced 
capacity of ki/ki M EFs to migrate on FN . In the mutants, the abnormal distribution of FN may actually represent a barrier to migrating cells. On the other hand, there are other several possible reasons for the observed branchial arch defects. First, there may be a defect in the formation of neural crest cells in the rhombomeres $r 2$ and $r 3$ of the hindbrain where they originate. Second, the paraxial mesoderm of the somites contributes to the outer layer of the first branchial arch and FN normally surrounds developing somites in a thin layer and appears to be essential for their formation (George et al. 1993). Although somites were clearly present at $11.5-16.5 \mathrm{dpc}$ in $\mathrm{ki} / \mathrm{ki}$ embryos, their rate of formation or their size may have been affected by the altered distribution of $\mathrm{FN}$ in $\mathrm{ki} / \mathrm{ki}$ embryos. Third, there may have been altered apoptosis on pathways followed by migrating neural crest cells, as described for PDGF receptor ko/ko embryos, with altered cell attachment compromising cell survival (Soriano 1997). Cell attachment-induced signaling, via integrins, seems to be a determinant for cell survival and growth (Chen et al. 1997; Frisch and Ruoslathi 1997; Merredith and Schwartz 1997). Fourth, $\beta 1 D$ might be less efficient than $\beta 1 A$ with regard to signaling induced by mechanical force; neural cell crest migration, which is mediated by cell-ECM interactions requires transmission of mechanical forces (Harris et al. 1980). The severe defects described above are unlikely to be lethal for the $\mathrm{ki} / \mathrm{ki}$ embryos. Of the $13 \mathrm{ki} / \mathrm{ki}$ embryos recovered at 12.5 dpc, 5 were, however, severely anemic. In viable ki/ki embryos recovered at other stages, there were RBC s outside the embryonic vasculature, randomly dispersed throughout various tissues and organs. This again resembles, to some extent, defects in the FN ko/ko mice (Georges et al. 1993), although the vasculature of the yolk sac had a normal appearance in the ki/ki mice. Because FN was only expressed at low levels in the smaller embryonic vessels, it is possible that these vessels may be weak and may rupture easily, which would lead to hemorrhage and death.

What do the knockin and knockout tell us about the function of $\beta 1 \mathrm{D}$ vs. $\beta 1 \mathrm{~A}$ ?

We have demonstrated that the splice variants $A$ and $D$ of $\beta 1$ are not functionally equivalent. From findings in our knockout mice, it is clear that $\beta 1 \mathrm{~A}$ does not completely compensate for $\beta 1 D$ because its replacement by $\beta 1 A$ results in mild heart dysfunction, suggesting that $\beta 1 D$ has some subtle function that is lacking in $\beta 1 A$. Therefore, it would be particularly interesting to look for genetic mutations in $\beta 1 D$ in patients with heart dysfunction of unknown etiology, because a disturbance of the balance between the two isoforms, $\beta 1 A$ and $\beta 1 D$, may be causally related to the dysfunction.

In contrast, in nonmuscular tissues, $\beta 1 D$ appeared to lack some of the functions of $\beta 1 A$. The lethality of the $\mathrm{ki} / \mathrm{ki}$ embryos clearly demonstrates that $\beta 1 \mathrm{~A}$ cannot be substituted by $\beta 1 D$. Reduced migratory activity of the $\mathrm{ki}$ / ki embryonic cells may be an important factor in contributing to the embryonic phenotype, because fibro- blasts isolated from mid-gestation embryos showed striking behavioral changes on different ECM proteins.

What might be the cause of the reduced migratory potential? First, we have observed that ki/ki MEFs have a $50 \%$ reduction in the level of the $\beta 1$ subunit, which is associated with a reduced level of the $\alpha 3, \alpha 5$, and $\alpha 6$ subunits. The reason for this reduced level of the $\beta 1 D$ protein remains unclear because the amounts of $\beta 1 \mathrm{~A}$ and $\beta 1 D$ mRN A are similar in ++ and ki/ki MEFs. It is possible that, when associated with another $\alpha$ subunit than the muscle-specific $\alpha 7$ subunit, the $\beta 1 D$ protein is less stable. Second, $\beta 1 D$ may be less efficient than $\beta 1 A$ in mediating migration, which is supported by the observation that even when we used concentrations of FN which gave $H+$ and $\mathrm{ki} / \mathrm{ki}$ MEFs the same adhesive capacity, the migratory activity of the ki/ki MEFs was not restored to control levels (Fig. 7). In addition, we found that on collagen IV, the migration rate of the $\mathrm{ki} / \mathrm{ki} \mathrm{MEFs}$ was greatly reduced without a parallel reduction in adhesion. Our observations are supported by the recent demonstration that increasing adhesion proportionally increases the migration rate of cel Is (Pal ecek et al. 1997). In conclusion, the reduced migratory potential of the embryonic cells is likely caused by a combination of reduced adhesion and a reduced migrating capacity, although we suspect that the latter is mainly responsible for the embryonic defects that we observed in the ki/ki embryos. This is supported by the observation that despite a $50 \%$ reduction in the expression level of the $\beta 1$, $\alpha 5$, and $\alpha 6$ subunits in the $\beta 1+/$ ko ES cells, the $\beta 1+/$ ko embryos developed normally (Fässler et al. 1995). Recently, it has been suggested that $\beta 1 \mathrm{~A}$ acts as a mechanotransducer in cultured cells (Wang et al . 1993) and in tissues (Shyy and Chien 1997). On the basis of our findings and the results of these previous studies, we suggest that $\beta 1 D$ acts as a mechanotransducer in muscle but with a lower efficiency than $\beta 1 A$. To some extent, migration may also be considered as a mechanotransduction process (Ingber et al . 1994). In cell migration, a cell spreads and thereby induces stretching and stiffening of the cytoskeleton (Lauffenburger and Horwitz 1996). If $\beta 1 D$ is less efficient than $\beta 1 A$ in mediating stress-induced signaling, then this might explain the reduced migratory capacity of the ki / ki embryonic cells. In addition to mechanical force-induced signaling, other types of extracellular signals might be less efficiently transduced by $\beta 1 D$ in the knockin embryonic cells. The loss of a potential site for phosphorylation and ILK binding in $\beta 1 D$ (Hannigan et al. 1996) could explain such a partially defective signaling pathway. Thus, our data suggest that probably because of a difference in their cytoplasmic domains, $\beta 1 D$, generally, transduces signals less efficiently than $\beta 1 \mathrm{~A}$.

\section{Materials and Methods}

Generation of $\beta 1 \mathrm{D}$ knockout mice

Genomic clones for the generation of the knockout and knockin targeting constructs were isolated from a 129/OLA genomic 
library (Stratagene), by use of a mouse $\beta 1$ integrin 3 '-end cDN A probe (probe 331). Three clones encoding the most downstream sequences of the $\beta 1$ gene $(\lambda 5, \lambda 7$, and $\lambda 8)$ were subcloned and analyzed by restriction enzyme mapping according to standard procedures (Sambrook et al. 1989). To construct the knockout targeting vector, the $\delta 8$ clone was used. BamHI sites were introduced by PCR mutagenesis on either side and in the close vicinity of exon $\mathrm{D}$. The DNA was digested with BamHI and exon $D$ with its ag/gt consensus splicing sites removed and replaced by a neo-tk cassette flanked by two loxP sites (a kind gift from Dr. R. Fässler, Max-Planck Institute, Munich, Germany). E14 ES cells were grown on mitotically inactivated MEF and electroporated with $80 \mu \mathrm{g}$ of linear targeting insert. After 8-10 days in neomycin-supplemented ES cell medium ( $200 \mu \mathrm{g} /$ $\mathrm{ml} \mathrm{G418),} \mathrm{colonies} \mathrm{were} \mathrm{isolated,} \mathrm{expanded,} \mathrm{and} \mathrm{screened} \mathrm{by}$ Southern blot. To del ete the sel ection markers, $2 \times 10^{6}$ targeted ES cells were retransfected with $1.5 \mu \mathrm{g}$ of supercoiled Cre-encoding plasmid DN A by electroporation. The transfected cells were plated on MEFs for $48 \mathrm{hr}$ and then replated at a density of $2 \times 10^{3}$ cells $/ \mathrm{cm}^{2}$. On day 3 after replating, $2 \mu \mathrm{m}$ Gancyclovir was included in the medium, and selection was continued for 5 days. Colonies surviving the sel ection were picked at days 8-10, and the deletion event was verified by PCR and Southern blot analysis. The following primers were used for the PCR: a $5^{\prime}$ primer 5'-cagtttatagtgtcaatacac-3' located upstream of the exon $D$. ES cell clones carrying the exon $D$ deletion were injected into C57BL/ 6 blastocysts, and the male chimeric mice were crossed with FVB and 129/OLA females to generate heterozygous mutant mice. Mice were genotyped by PCR. DNA from tail biopsies were isolated by proteinase $K$ digestion followed by isopropanol precipitation.

\section{Generation of $\beta 1 D$ knockin mice}

To construct the TC 8 knockin targeting vector, we used the genomic clone $\delta 8$ (see above). A $\beta 1 D$-encoding cDN A fragment was generated by PCR by use of a $\beta 1 D$ cDN A clone as a template (Baudoin et al. 1996). This fragment encompasses exons 6 , $D$, and 7 of the $\beta 1 D$ CDNA (Tominaga 1988) and contains unique Munl and Apal restriction sites located, respectively, in exons 6 and 7 (Baudoin et al. 1996). The $\delta 8$ clone DNA was digested with Munl and A pal. After digestion, the genomic region, containing exons $6, D, 7$, and their intronic sequences, was removed and the $\delta 8$ DN A ligated to the Munl-A pal $\beta 1 D$-encoding CDNA fragment. This replacement results in a constitutive expression for the $\beta 1 D$ subunit. For positive selection, a neomycin cassette was introduced into the construct by use of an A pal site located between the two polyadenylation signals of the $\beta 1$ integrin gene. Electroporation, selection with G418, screening of the neomycin-resistant ES cell colonies, and blastocysts injection were done with the same protocol followed for the knockout experiment.

\section{Southern blot, Northern blot, and Western blot analysis}

For Southern blot analysis, ES cells and mouse DNA were digested with the BamHI or Xbal enzymes and the blots were hybridized with the 331 probe according to standard procedures (Sambrook et al. 1989). For Northern blot analysis of $\beta 1 D$ expression, ES cells and mouse total RN A $(10 \mu \mathrm{g})$ were hybridized to an ${ }^{32} \mathrm{P}$-labeled antisense oligonucleotide (5'-gagaccagctttacgtccatagttgggattcttgaaatt- $3^{\prime}$ ) specific for exon D. The blot was hybridized and washed by standard conditions and autoradiographed overnight. For Northern blot analysis of AN P expression, a cDN A probe was generated by RT-PCR amplification by use of the following primers deduced from the ANP CDNA se- quence (Seidman et al. 1984): upstream primer $5^{\prime}$-ccaggccatattggagcaaa-3' and downstream primer $5^{\prime}$-gaagctgttgcagcctagtc- $3^{\prime}$. For Western blot analysis, various adult mouse tissues were homogenized in RIPA buffer and spun down. Proteins from the supernatant $(40 \mu \mathrm{g})$ were electrophoresed on $8 \%$ SDS-PAGE (Laemmli 1970) and transferred onto Immobilon membranes. Blots were blocked with $2 \%$ milk powder in TBST for $1 \mathrm{hr}$. Blots were then incubated with primary antibodies and secondary peroxydase-conjugated anti bodies, washed and devel oped by use of ECL reagents (Amersham).

\section{Immunohistochemistry and histological analysis}

For histology, mouse tissues or embryos were fixed in formalin, paraffin embedded, sectioned, and stained with hematoxylin and eosin according to standard procedures (Smith and Bruton 1978). For immunohistochemistry of mouse adult tissues, 5- $\mu \mathrm{m}$ cryosections were cut at $-20^{\circ} \mathrm{C}$ and collected on silane-coated slides and air dried. Immunohistochemistry was carried out by standard protocols. FN and $\alpha 5$ integrin were stained on fixed paraffin sections. Primary antibodies used were rat anti-mouse$\beta 1$ (MB1.2) (von Ballestrem et al. 1996), rat anti- $\beta 1$ (9EG7) (Lenter et al. 1993), rabbit anti- $\beta 1 A c y t o$ and rabbit anti- $\alpha 5$ (DeFilippi et al. 1991), rabbit anti- $\alpha$ V (Hirsch et al. 1994), mouse anti- $\alpha 3 A$ (29A3), mouse anti- $\alpha 3 B$ (54B3) (De Melker et al . 1997), rat anti-mouse $\alpha 7$ (CA5) (Yao et al. 1996), rabbit anti- $\alpha 7 A$ cyto (a7CDA2), rabbit anti- $\alpha$ 7Bcyto (a7CDB1) (Martin et al. 1996), mouse anti- $\beta 1 D$ (2B1) (van der Flier et al. 1997), mouse antidystrophin (M andra 1, Sigma, ref. D-8043), and goat anti-fibronectin (Sigma, ref. F-1509).

\section{Analysis of knockin embryos}

Embryos were dissected as described previously (Cockroft 1990). Embryos were fixed in 4\% paraformal dehyde for $4-6 \mathrm{hr}$ at $4^{\circ} \mathrm{C}$, dehydrated with ethanol, cleared in butanol, and embedded in paraffin. Sections $(10 \mu \mathrm{m})$ were stained with hematoxylin and eosin, examined, and photographed. Only defects found in at least five embryos were described. Genomic DN A was extracted from the yolk sacs and genotyped by PCR or Southern blot analysis.

\section{Culture of knockin MEFs}

To culture embryonic cells, the whole E12.5 embryo was washed twice in DMEM and dissociated with sterile tweezers. The minced tissues from single embryos were trypsinized for 5 $\min$ at $37^{\circ} \mathrm{C}$ and the suspension of each embryo plated in a T75 flask with $25 \mathrm{ml}$ of DMEM supplemented with $10 \%$ FCS. Cells were subcultured three times to obtain a homogenous population of fibroblastic cells. The genotype of each embryonic cell culture was tested by PCR and Southern blot analysis.

\section{Adhesion and chemotactic migration assays}

Chemotactic cell migration was performed as described (Grotendorst 1984) in a Boyden chamber-type with polycarbonate filters (8- $\mu \mathrm{m}$ pores; Transwell, Costar) coated on both si des with different ECM proteins. MEFs were trypsinized, washed once with DMEM containing $0.1 \%$ BSA, resuspended in the same medium at the density of $5 \times 10^{5} \mathrm{cel} / \mathrm{s} / \mathrm{ml}$, and introduced in the upper compartment of the chamber $(100 \mu \mathrm{l})$. The lower compartment contained $500 \mu \mathrm{l}$ of DMEM supplemented with 25 $\mathrm{ng} / \mathrm{ml} \mathrm{PDGF}$. After 1,2 , or $3 \mathrm{hr}$ at $37^{\circ} \mathrm{C}$ cells that had migrated on the lower side were fixed, stained with crystal violet, and eight microscopic fields per filter counted. For adhesion assays, 
the attachment of MEFs to ECM proteins followed procedures described previously (Aumailley et al. 1989). Tissue culture 96well plastic plates were coated with ligands at $4^{\circ} \mathrm{C}$ overnight. After blocking with $1 \%$ BSA, $5 \times 10^{4}$ MEFs resuspended in 100 $\mu \mathrm{l}$ of DMEM was added to each well and incubated for 20-40 min, depending on the ligand, at $37^{\circ} \mathrm{C}$. Wells were washed with PBS, and the attached cells were fixed with $1 \%$ glutaral dehyde, stained with $0.1 \%$ crystal violet for $30 \mathrm{~min}$, and washed extensively with water. Cell-bound stain was measured at $550 \mathrm{~nm}$ in an ELISA reader after solubilization with $0.2 \%$ Triton X-100. ECM proteins were human vitronectin (Preissner et al. 1985), pepsinized human collagen type IV (Vandenberg et al. 1991), mouse laminin 1 (Paulsson et al. 1985), and human plasma FN (Sigma Chemical).

\section{Acknowledgments}

We thank R. van der Valk, M. van Rooijen, and J. Korving for histological analysis of the mice; L. Oomen for confocal laser scanning microscopy; D. Kramer for FACS analysis; D. Prins for PCR analysis of mice DNA; F. Veerbeek with embryo illustrations; and $A$. van der Flier for generating and providing us with the $2 \mathrm{~B} 1$ antibody. We also thank S.J. Kaufman for the $\alpha 7 \mathrm{~A}$ and $\alpha 7 B$ antisera; G. Tarone for the $\beta 1 A, \alpha 5$, and $\alpha v$ antisera; B.M.C. $C$ han and $D$. Westerber for the rat monoclonal antibodies to murine $\beta 1$, MB1.2, and 9EG 7, respectively; R. Kramer for the rat monocl onal antibody to murine $\alpha 7 ; \mathrm{K}$. Preissner for human vitronectin; K. Kühn for human collagen IV; and R. Timpl for mouse laminin. We are grateful to J.L. Samuel for her hel $p$ and advice; R. Fässler for providing us with the neo-tk cassette and many useful suggestions; and L. Borradori, R. van der N eut, E. Roos, C.P.E. Engelfriet, and the several colleagues in our laboratory for critical comments on the manuscript. Finally, special thanks go to C. Gimond for her contribution to the adhesion assays. All of the ES cell work was carried out in the ES cell Iaboratory of the N etherlands Cancer Institute (Prof. A. Berns). This work was supported by a Training and Mobility of Researchers $M$ arie Curie Research training grant from the European Commission (ERBFMBICT961823 to C.B.) and a grant (N HS 96.006) from the N etherlands Heart Foundation (to A.S.).

The publication costs of this article were defrayed in part by payment of page charges. This article must therefore be hereby marked "advertisement" in accordance with 18 USC section 1734 solely to indicate this fact.

\section{References}

Almeida, E.A.C., A.P.J. Huovila, A.E. Sutherland, L.E. Stephens, P.G. Calarco, L.M. Shaw, A.M. Mercurio, A. Sonnenberg, P. Primakoff, D.G. Myles, and J.M. White. 1995. Mouse egg integrin $\alpha 6 \beta 1$ functions as a sperm receptor. Cell 81: 10951104.

Altruda, F., P. Cervella, G. Tarone, C. Botta, F. Balzac, G. Stefanuto, and L. Silengo. 1990. A human integrin $\beta 1$ subunit with a unique cytoplasmic domain generated by alternative mRN A processing. Gene 95: 261-266.

Aumailley, M., K. M ann, H. von der M ark, and R. Timpl. 1989. Cell attachment properties of collagen type IV and Arg-GlyAsp dependent binding to its $\alpha 2(\mathrm{VI})$ and $\alpha 3(\mathrm{VI})$ chains. Exp. Cell. Res. 181: 463-474.

Baudoin, C., A. Van der Flier, L. Borradori, and A. Sonnenberg. 1996. Genomic organization of the mouse $\beta 1$ gene: Conservation of the $\beta 1 D$ but not of the $\beta 1 B$ and $\beta 1 C$ integrin splice variants. Cell Adhes. Commun. 4: 1-11.

Belkin, A.M., N .I. Zhidkova, F. Balzac, F. Altruda, D. Tomatis,
A. M aier, G. Tarone, V.E. Koteliansky, and K. Burridge. 1996. $\beta 1 D$ integrin displaces the $\beta 1 \mathrm{~A}$ isoform in striated muscles: Localization at junctional structures and signal ing potential in nonmuscle cells. J. Cell. Biol. 132: 211-226.

Brandt, R.R., R.S. Wright, M.M. Redfield, and J.C. Burnett. 1993. Atrial natriuretic peptide in heart failure. J. Am. Coll. Cardiol. 22: 86A-92A.

Brooks, S.E., M.A. Douglas, M.E. Lee, G.S. Reeder, L.E. Wold, and J.C. Burnett. 1988. Identification of atrial natriuretic factor within ventricular tissue in hamsters and humans with congestive heart failure. J. Clin. Invest. 81: 82-86.

Chen, C.S., M. Mrksich, S. Huang, G.M. Whitesides, and D.E. Ingber. 1997. Geometric control of cell life and death. Science 276: 1425-1428.

Cockroft, D.L. 1990. Dissection and culture of postimplantation embryos. In Postimplantation mammalian embryos, a practical approach (ed. A.J. Copp and D.L. Cockroft), pp. 15-40. Oxford University Press, Oxford, UK.

Defilippi, P., V. Van Hinsbergh, A. Bertolotto, P. Rossino, L. Silengo, and G. Tarone. 1991. Differential distribution and modulation of expression of $\alpha 1 \beta 1$ integrin on human endothelial cells. J. Cell. Biol. 114: 855-863.

De Melker, A.A., L.M.T. Sterk, G.O. Delwel, D.L.A. Fles, H. Daams, J.J. Weening, and A. Sonnenberg. 1997. The A and B variants of the $\alpha 3$ integrin subunit: Tissue distribution and functional characterization. Lab. Invest. 76: 547-563.

DiSanto, J.P., W. Muller, D. Guy-Grand, A. Fischer, and K. Rajewsky. 1995. Lymphoid development in mice with targeted deletion of the interleukin 2 receptor $\gamma$ chain. Proc. Natl. Acad. Sci. 92: 377-381.

Erdos, T., G. Butler-Browne, and L. Rappaport. 1991. Mechanogenetic regulation of transcription. Biochimie 73: 1219-1231.

Fässler, R., M. Pfaff, J. Murphy, A.A. N oegel, S. Johansson, R. Timpl, and R. Albrecht. 1995. Lack of $\beta 1$ integrin gene in embryonic stem cells affects morphology, adhesion, and migration but not integration into the inner cell mass of blastocysts. J. Cell. Biol. 128: 979-988.

Fässler, R., J. Rohwedel, V. Maltsev, W. Bloch, S. Lentini, K. Guan, D. Gullberg, J. Hescheler, K. Addicks, and A.M. Wobus. 1996. Differentiation and integrity of cardiac muscle cells are impaired in the absence of $\beta 1$ integrin. J. Cell. Sci. 109: 2989-2999.

Frisch, S.M . and E. Ruoslathi. 1997. Integrins and anoikis. Curr. Opin. Cell. Biol. 9: 701-706.

Galileo, D.S., J. M ajors, A.F. Horwitz, and J.R. Sanes. 1992. Retrovirally introduced antisense integrin RNA inhibits neuroblast migration in vivo. Neuron 9: 1117-1131.

George, E.L., E.N. Georges-Labouesse, R.S. Patel-King, H. Rayburn, and R.O. Hynes. 1993. Defects in mesoderm, neural tube and vascular development in mouse embryos lacking fibronectin. Development 119: 1079-1091.

Gordon, R. and G.W. Brodl and. 1987. The cytoskel etal mechanics of brain morphogenesis: Cell state splitters cause primary neural induction. Cell. Biophys. 11: 177-238.

Grotendorst, G.R. 1984. Alteration of the chemotactic response of $\mathrm{NIH} / 3 \mathrm{~T} 3$ cells to PDGF by growth factors, transformation, and tumor promotors. Cell 36: 279-285.

Gu, H., J.D. M arth, P.C. Orban, H. M ossmann, and K. Rajewsky. 1994. Deletion of a DNA polymerase $\beta$ gene segment in T cells using cell type-specific gene targeting. Science 265: 103-106.

Hanks, M., W. Wurst, L.A. Anson-Cartwright, A.B. Auerbach, and A.L. Joyner. 1995. Rescue of the En-1 mutant phenotype by replacement of En-1 with En-2. Science 269: 679-682.

Hannigan, G.E., C. Leunghagesteijn, L. Fitzgibbon, M.G. Cop- 
polino, G. Radeva, J. Filmus, J.C. Bell, and S. Dedhar. 1996. Regulation of cell adhesion and anchorage-dependent growth by a new $\beta 1$-integrin-linked protein kinase. Nature 379: 91-96.

Harris, A.K., P. Wild, and D. Stopack. 1980. Silicone rubber substrata: A new wrinkle in the study of cell locomotion. Science 208: 177-180.

Hirsch, E., D. Gullberg, F. Balzac, F. Altruda, L. Silengo, and G. Tarone. 1994. $\alpha \mathrm{V}$ integrin subunit is predominantly located in nervous tissue and skeletal muscle during mouse development. Dev. Dyn. 201: 108-120.

Hynes, R.O. 1992. Integrins: Versatility, modulation, and signaling in cell adhesion. Cell 69: 11-25.

Ingber, D.E., L. Dike, L. Hansen, S. Karp, H. Liley, A. Maniotis, H. M cN amee, D. M ooney, G. Plopper, J. Sims, and N. Wang. 1994. Cellular tensegrity: Exploring how mechanical changes in the cytoskel eton regulate cell growth, migration, and tissue pattern during morphogenesis. Int. Rev. Cytol. 150: 173-225.

Izumo, S., A.M. Lompre, R. M atsuoka, G. Koren, K. Schwartz, B. $\mathrm{N}$ adal-Ginard, and V. Mahdavi. 1987. Myosin heavy chain mRN A and protein isoform transitions during cardiac hypertrophy. J. Clin. Invest. 79: 970-977.

Jaffredo, T., A.F. Horwitz, C.A. Buck, P.M. Rong, and F. Dieterlen-Lievre. 1988. Myoblast migration specially inhibited in the chick embryo by grafted CSAT hybridoma cells secreting an anti-integrin antibody. Development 103: 431-446.

Jarygin, C., J. Hanze, and R.E. Lang. 1994. Gene expression of atrial natriuretic peptide in rat papillary muscle. Rapid induction by mechanical loading. FEBS Lett. 364: 185-188.

Laemmli, U.K. 1970. Cleavage of structural proteins during the assembly of the head of bacteriophage T4. Nature 227: 23439-23442.

Languino, L.R. and E. Ruoslahti. 1992. An alternative form of the integrin $\beta 1$ subunit with a variant cytoplasmic domain. J. Biol. Chem. 267: 7116-7120.

Lauffenburger, D.A. and A.F. Horwitz. 1996. Cell migration: A physically integrated molecular process. Cell 84: 359-369.

Lee, R.T., K.D. Bloch, M.A. Pfeffer, E.J. N eer, and C.E. Seidman. 1988. Atrial natriuretic factor gene expression in ventricles of rats with spontaneous biventricular hypertrophy. J. Clin. Invest. 81: 431-434.

Lenter, M., H. Uhlig, A. Hamann, P. Jenö, B. Imhof, and D. Vestweber. 1993. A monoclonal antibody against an activation epitope on mouse integrin chain $\beta 1$ blocks adhesion of lymphocytes to the endothelial integrin $\alpha 6 \beta 1$. Proc. Natl. Acad. Sci. 90: 9051-9055.

Martin, P.T., S.J. Kaufman, R.H. Kramer, and J.R. Sanes. 1996. Synaptic integrins in developing, adult, and mutant muscle: Selective association of $\alpha 1, \alpha 7 A$, and $\alpha 7 B$ integrins with the neuromuscular junction. Dev. Biol. 174: 125-139.

Martin-Bermudo, M.D. and N.H. Brown. 1996. Intracellular signals direct integrin localization to sites of function in embryonic cells. J. Cell. Biol. 134: 217-226.

Mayer, U., G. Saher, R. Fässler, A. Bornemann, F. Echtermeyer, H. von der Mark, N. Miosge, E. Pöschl, and K. von der M ark. 1997. Absence of integrin $\alpha 7$ causes a novel form of muscuIar dystrophy. Nature Genet. 17: 318-323.

Merredith, J.E., Jr., and M.A. Schwartz. 1997. Integrins, adhesion and apoptosis. Trends Cell. Biol. 7: 146-150.

Morita, H., I. Tanaka, T. Oda, A. Ichimaya, T. Yamasaki, T. Uematsu, M. N akashima, and T. Yoshimi. 1990. Atrial natriuretic peptide mRNA and pepide in rats with aortic valve insufficiency. Peptides 11: 843-847.

Morrison-Graham, K., G.C. Scatteman, T. Bork, D.F. Bowen-
Pope, and J.A. Weston. 1992. A PDGF receptor mutation in the mouse (patch) pertubs the development of non-neural crest-derived cells. Development 115: 133-142.

Nakao, K., H. Itoh, Y. Saito, M. Mukoyama, and Y. Ogawa. 1996. The natriuretic peptide family. Curr. Opin. Nephrol. Hypertens. 5: 4-11.

Palecek, S.P., C. Loftus, M.H. Ginsberg, D.A. Lauffenburger, and A.F. Horwitz. 1997. Integrin-ligand binding properties govern cell migration speed through cell-substratum adhesiveness. Nature 385: 537-540.

Paulsson, M.R., R. Deutzmann, R. Timpl, R. Dalzoppo, E. Odermatt, and J. Engel. 1985. Evidence for coiled-coil $\alpha$-helical regions in the long arm of laminin. 1985. EMBO J. 4: 309316.

Preissner, K.T., R. Wassmuth, and G. Muller-Berghaus. 1985. Physicochemical characterization of human s-protein and its function in the blood coagulation system. Biochem. J. 231: 349-355.

Sambrook, J., E.F. Fritsch, and T. Maniatis. 1989. Molecular cloning. A laboratory manual. Cold Spring Harbor Laboratory Press, Cold Spring Harbor, NY.

Schwartz, M.A., M.D. Schaller, and M.H. Ginsberg. 1995. Integrins-emerging paradigms of signal-transduction. Annu. Rev. Cell. Dev. Biol. 11: 549-599.

Seidman, C.E., K.D. Bloch, K.A. Klein, J.A. Smith, and J.G. Seidman. 1984. Nucleotide sequences of the human and mouse atrial natriuretic factors genes. Science 226: 12061209.

Shyy, J.Y.J. and S. Chien. 1997. Role of integrins in cellular responses to mechanical stress and adhesion. Curr. Opin. Cell. Biol. 9: 707-713.

Smith, A. and J. Bruton. 1978. A colour atlas of histological staining techniques. Wolfe Medical Atlases, no. 18. Wolfe Medical Publications Ltd., London, UK.

Smith, A.J., M.A. De Sousa, B. Kwabi-Addo, A. Heppell-Parton, H. Impey, and P. Rabbitts. 1995. A site-directed chromosomal translocation induced in embryonic stem cells by CreIoxP recombination. Nature Genet. 9: 376-385.

Sonnenberg, A. 1993. Integrins and their ligands. Curr. Top. Microbiol. Immunol. 184: 7-35.

Soriano, P. 1997. The PDGF $\alpha$ receptor is required for neural crest cell development and for normal patterning of the somites. Development 124: 2691-2700.

Stephens, L.E., A.E. Sutherland, I.V. Klimanskaya, A. Andrieux, J. Meneses, R.A. Pedersen, and C.H. Damsky. 1995. Deletion of $\beta 1$ integrins in mice results in inner cell mass failure and peri-implantation lethal ity. Genes \& Dev. 9: 1883-1895.

Sutherland, A.E., P.G. Calarco, and C.H. Damsky. 1993. Developmental regulation of integrin expression at the time of implantation in the mouse embryo. Development 119: $1175-1186$.

Thiery, J.P., J.L. Duband, and G.C. Trucker. 1985. Cell migration in the vertebrate embryo: Role of cell adhesion and tissue environment in pattern formation. Annu. Rev. Cell. Biol. 1: 91-113.

Tiidus, P.M. 1995. Can estrogens diminish exercise-induced muscle damage? Can. J. A ppl. Physiol. 20: 26-38.

Tominaga, S. 1988. Murine mRN A for the $\beta$-subunit of integrin is increased in Balb/c-3T 3 cells entering the $G 1$ phase from the Go phase. FEBS Lett. 238: 315-319.

Vandenberg, P., A. Kern, A. Ries, L. Luckenbill-Edds, K. Mann, and K. Kühn. 1991. Characterization of a type IV collagen major cell binding site with affinity to the $\alpha 1 \beta 1$ and $\alpha 2 \beta 1$ integrins. J. Cell. Biol. 113: 1475-1483.

van der Flier, A., I. Kuikman, C. Baudoin, R. Van der N eut, and A. Sonnenberg. 1995. A novel $\beta 1$ integrin isoform produced 


\section{Baudoin et al.}

by alternative splicing: Unique expression in cardiac and skeletal muscles. FEBS Lett. 369: 340-344.

van der Flier, A., A.C. Gaspar, S. Thorsteindóttir, C. Baudoin, E. Groeneveld, C.L. Mummery, and A. Sonnenberg. 1997. Spatial and temporal expression of the $\beta 1 D$ integrin during mouse development. Dev. Dyn. 210: 472-486.

Velling, T., G. Collo, L. Sorokin, M. Durbeej, H. Zhang, and D. Gullberg. 1996. Distinct $\alpha 7 A \beta 1$ and $\alpha 7 B \beta 1$ integrin expression patterns during mouse development: $\alpha 7 A$ is restricted to skeletal muscle but $\alpha 7 \mathrm{~B}$ is expressed in striated muscle, vasculature, and nervous system. Dev. Dyn. 207: 355-371.

Volk, T., L.I. Fessler, and J.H. Fessler. 1990. A role for integrin in the formation of sarcomeric cytoarchitecture. Cell 63: 525536.

Von Ballestrem, C.G., S. Uniyal, J.I. McCormick, T. Chau, B. Singh, and B.M.C. Chan. 1996. VLA- $\beta 1$ integrin subunit-specific monoclonal antibodies MB1.1 and MB1.2: Binding to epitopes is not dependent on thymocyte development or regulated by phorbol ester and divalent cations. Hybridoma 15: 125-132.

Wang, N., J. Butler, and D. Ingber. 1993. M echanotransduction across the cell surface and through the cytoskel eton. Science 260: 1124-1127.

Wennerberg, K., L. Lohikangas, D. Gullberg, M. Pfaff, S. Johansson, and R. Fässler. 1996. $\beta 1$ integrin-dependent and -independent polymerization of fibronectin. J. Cell. Biol. 132: 227-238.

Wu, C., V. Keivens, T.E. O'T oole, J. McDonald, and M.H. Ginsberg. 1995. Integrin activation and cytoskeletal interaction are essential for the assembly of a fibronectin matrix. Cell 83: 715-724.

Yang, J.T. and R.O. Hynes. 1996. Fibronectin receptor functions in embryonic cells deficient in $\alpha 5 \beta 1$ integrin can be replaced by $\alpha$ v integrins. Mol. Cell. Biol. 7: 1737-1748.

Yang, J.T., H. Rayburn, and R.O. Hynes. 1993. Embryonic mesodermal defects in $\alpha 5$ integrin-deficient mice. Development 119: 1093-1105.

Yang, J.T., T.A. Rando, W.A. Mohler, H. Rayburn, H.M. Blau, and R.O. Hynes. 1996. Genetic analysis of $\alpha 4$ integrin functions in the development of mouse skeletal muscle. J. Cell. Biol. 135: 829-835.

Yao, C.C., B.L. Ziober, A.E. Sutherland, D.L. Mendrick, and R.H. Kramer. 1996. Laminins promote the locomotion of skel etal myoblasts via the $\alpha 7$ integrin receptor. J. Cell. Sci. 109: 3139-3150.

Zhidkova, N.I., A.M. Belkin, and R. Mayne. 1995. Novel isoform of $\beta 1$ integrin expressed in skeletal and cardiac muscles. Biochem. Biophys. Res. Commun. 214: 279-285. 


\section{Conigendum}

Genes \& Development 12: 1202-1216 (1998)

Knockout and knockin of the $\beta 1$ exon $D$ define distinct roles for integrin splice variants in heart function and embryonic development

Christian Baudoin, M arie-José Goumans, Christine M ummery, and Arnoud Sonnenberg

The integrin $\alpha \mathrm{V} \beta 6$ mentioned on page 1209, first paragraph under "Reduced migratory potential of $\beta 1 \mathrm{D}$ knockin embryonic cells" (line 12 down) and in Figure 8B (right panel, last lane) is incorrect. It should be the integrin $\alpha \mathrm{V} \beta 5$. The authors regret this error. 


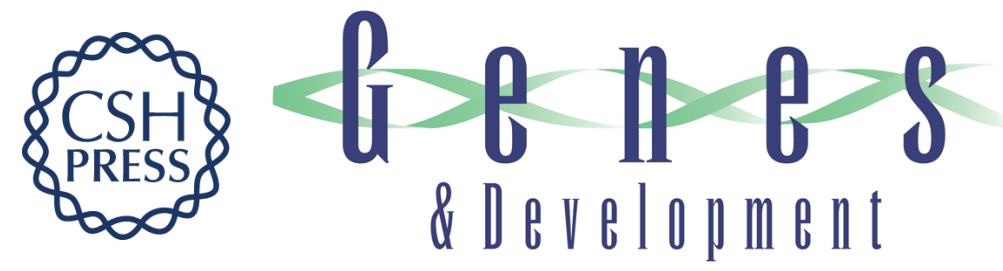

\section{Knockout and knockin of the $\beta 1$ exon $D$ define distinct roles for integrin splice variants in heart function and embryonic development}

Christian Baudoin, Marie-José Goumans, Christine Mummery, et al.

Genes Dev. 1998, 12:

Related Content Corrigendum for vol. 12, p. 1202

Genes Dev. June, 1998 12: 1749

References This article cites 64 articles, 26 of which can be accessed free at: http://genesdev.cshlp.org/content/12/8/1202.full.html\#ref-list-1

Articles cited in:

http://genesdev.cshlp.org/content/12/8/1202.full.html\#related-urls

License

Email Alerting Receive free email alerts when new articles cite this article - sign up in the box at the top

Service right corner of the article or click here.

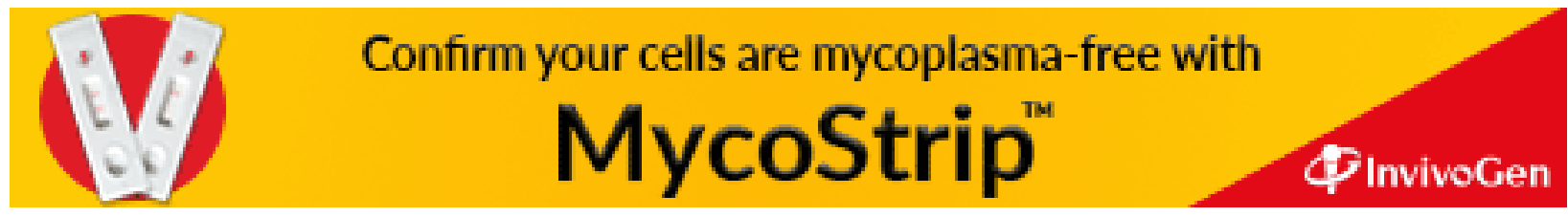

